\title{
Ice Stream retreat following the LGM and onset of the West Greenland Current in Uummannaq Trough, West Greenland
}

Christina Sheldon ${ }^{1}$, Anne Jennings², John T. Andrews², Colm Ó Cofaigh ${ }^{3}$, Kelly Hogan ${ }^{4}$, Julian A. Dowdeswell $^{5}$, Marit-Solveig Seidenkrantz ${ }^{1}$

${ }^{1}$ Centre for Past Climate Studies and Arctic Research Centre, Department of Geoscience, Aarhus University, Aarhus, Denmark

Author email: christina.sheldon@geo.au.dk

Phone number: +13032491503

Fax number: +45 87150201

${ }^{2}$ INSTAAR and Department of Geological Sciences, University of Colorado, Boulder, Colorado 80309, USA

${ }^{3}$ Department of Geography, Durham University, Durham, United Kingdom

${ }^{4}$ British Antarctic Survey, High Cross, Madingley Road, Cambridge CB3 0ET, United Kingdom ${ }^{5}$ Scott Polar Research Institute, University of Cambridge, Cambridge CB2 1ER, United Kingdom

Keywords: Uummannaq Trough, ice stream retreat, West Greenland Current, foraminifera 


\section{Abstract}

The deglacial history and oceanography of Uummannaq Trough, central West Greenland continental shelf, was investigated using foraminiferal, sedimentological, and bathymetric records together with a radiocarbon chronology, providing a timeline for the retreat of glacial ice after the Last Glacial Maximum (LGM). To map ice stream retreat, data were collected from cores from the outer (JR175-VC45 and JR175-VC43) and inner (JR175-VC42) Uummannaq Trough. A large ice stream, fed by confluent glaciers draining the interior of the Greenland Ice Sheet, extended across the outer shelf during the LGM and was retreating by $15.0 \mathrm{cal}$ kyr BP. Foraminiferal data indicate that the 'warm' West Greenland Current (WGC) was established prior to $14.0 \mathrm{cal}$ kyr BP, which is the hitherto earliest record of Atlantic Water found on the West Greenland shelf. For each of the cores, foraminifera indicate that ice sheet retreat was followed quickly by incursion of the WGC, suggesting that the warm water may have enhanced ice retreat. Prior to the Younger Dryas cold event, the existing radiocarbon chronology indicates that the ice sheet retreated to the mid-shelf, where it subsequently stabilised and formed a large grounding-zone wedge (GZW). After the Younger Dryas, around $11.5 \mathrm{cal}$ kyr BP, the ice retreated rapidly from the GZW and into the fjords. 


\section{Introduction}

The recent rapid increase of mass loss from the Greenland Ice Sheet (GIS) (Joughin et al., 2012; Rignot et al., 2011; Rignot and Kanagaratnam, 2006; van den Broeke et al., 2009) underscores its potentially significant contribution to sea level rise in the coming century (Nick et al., 2009, 2013). A growing body of evidence supports the idea that the advection of warm ocean water to the grounding line of Greenland's outlet glaciers promotes rapid melting (Joughin et al., 2012; Rignot, 2002), increasing ice-flow rates and thinning of marineterminating outlet glaciers (Howat et al., 2007), which together lead to retreat of tidewater ice streams (Bindschadler, 2006; Holland et al., 2008; Straneo et al., 2010, 2011). The presentday rapid response of the GIS to modern climatic warming and ocean forcing can be placed into a longer-term context by studying the rate, timing, and drivers of ice sheet retreat from the maximum ice advance during the LGM and comparing this retreat history to the coeval climate oscillations recorded in ice cores (Alley et al., 2010; Long, 2009).

Recent work has shown that two of the large cross-shelf troughs in central West Greenland, the Disko and Uummannaq troughs, contained fast-flowing ice streams that drained the Jakobshavns and Uummannaq glacial systems and extended to the shelf edge where they delivered sediments to large trough-mouth fans (Ó Cofaigh et al., 2013a, 2013b; Dowdeswell et al., 2014). In Disko Trough the LGM ice retreat was overprinted by a late Younger Dryas ice re-advance to the shelf edge (Jennings et al., 2014; Ó Cofaigh et al., 2013b). In contrast, the record of LGM ice retreat from the outer shelf is undisturbed in Uummannaq Trough. The timeline of the Uummannaq ice stream retreat is constrained by two radiocarbon dates (Fig. 1b). A date from glacimarine sediments only $5 \mathrm{~cm}$ above basal till in the outer shelf core JR175-VC45 (Fig. 1) indicates that the ice margin had retreated from the outer shelf by 14.9 
cal kyr BP (Ó Cofaigh et al., 2013b). A date from glacimarine sediments in core MSM343520 (Fig. 1) indicates that the ice stream had retreated from the middle shelf by at least $10.9 \mathrm{cal}$ kyr BP (McCarthy, 2011). Cosmogenic isotope ages from the adjacent coastal area suggest that Uummannaq ice stream was thinning dramatically by the end of the Younger Dryas and that the ice margin had retreated into the fjords by $11.4 \mathrm{kyr}$, implying rapid ice retreat from the deep trough on the inner shelf (Lane et al., 2014; Roberts et al., 2013).

A $>40$ m thick grounding-zone wedge (GZW) on the middle shelf was formed by delivery of deforming subglacial sediments to the front of the Uummannaq ice stream during a pause in the ice retreat from the LGM position close to the shelf edge (Dowdeswell et al., 2014). This submarine landform, with the characteristic long-profile asymmetry typical of GZWs (Batchelor and Dowdeswell, 2015; Dowdeswell and Fugelli, 2012), is evident between the 400 and $500 \mathrm{~m}$ depth contours on the middle shelf (Fig. 1b and 2a). This large GZW, plus two smaller ones identified on the inner shelf, indicate that ice retreat in the Uummannaq Trough was episodic (Dowdeswell et al., 2008, 2014). The size and thickness of the large mid-shelf GZW suggests that decades to centuries were required for its construction (Dowdeswell et al., 2014). The GZW age is unknown, but, based on the two constraining ages on the outer and mid shelf, it must have formed during a stillstand that occurred between 14.9 and $10.9 \mathrm{cal} \mathrm{kyr}$ BP. Formation created by a possible re-advance during this period cannot be ruled out, but no data exist to corroborate this.

Here, we present a study of the palaeoenvironments and history of post-LGM ice retreat in the Uummannaq Trough. Using sedimentary lithofacies, ice-rafted detritus (IRD), foraminifera, mineralogy, geophysical data (see Dowdeswell et al., 2014) and radiocarbon dating from the 
cores, we explore the palaeoenvironments and sedimentary processes operating during ice retreat, the possibility of a major stillstand during deglaciation, and test the hypothesis that 'ocean forcing' or advection of relatively warm Atlantic Water sustained ice retreat.

\section{Environmental Setting and Previous Work}

The continental margin of West Greenland meets Baffin Bay in a series of deep cross-shelf troughs that terminate at the shelf edge and often have trough-mouth fans (TMFs) beyond them on the slope (Batchelor and Dowdeswell, 2014) (Fig. 1b). The TMFs were built by repeated advances of the GIS to the shelf edge during Quaternary glaciations (Ó Cofaigh et al., 2013a). The Uummannaq Trough ends in a large TMF that comprises glacigenic-debris flows in the upper part of the fan and hemipelagic, iceberg-rafted sediments and turbidites on the northern fan (Dowdeswell et al., 2014; Ó Cofaigh et al., 2013a). The trough meets the upper slope at $700 \mathrm{~m}$ water depth, and shallows eastward to $450 \mathrm{~m}$ water depth on the mid shelf at the location of a large GZW, which forms a bathymetric high, and then deepens eastward to $700 \mathrm{~m}$ water depth as the trough reaches the fjord mouths (Fig. 2a).

Sub-glacial erosion transports sediments across the continental shelf, providing a record of sedimentary provenance along the path of the glacier. Therefore, the bedrock composition of the Uummannaq region is important for tracing the ice stream retreat. The bedrock of Uummannaq Trough and the fjords that enter the trough is composed of metamorphosed granitic Precambrian shield covered by kaolinite-rich Cretaceous sediments, which are overlain by sedimentary and basaltic formations in the western fjords (Mowatt and Naidu, 1994; Pedersen and Pulvertaft, 1992). The southern fjords of the Uummannaq system have exposed reworked Archaean basement (Escher and Pulvertaft, 2010), and the eastern fjords 
contain Palaeoproterozoic supracrustal metamorphosed sedimentary rock (Escher and Pulvertaft, 2010; Mowatt and Naidu, 1994). The southeastern fjords in the Uummannaq area contain calcitic marble, while the northwestern fjords contain some traces of calcite and dolomite in the Karrat sediment group (Steenfelt et al., 1998). Nevertheless, the main sources of detrital carbonate, which generally characterise Heinrich (H)/Detrital Carbonate (DC) events, known as Baffin Bay detrital carbonate (BBDC) events in Baffin Bay (Andrews et al., 1998; Andrews and Eberl, 2011; Simon et al., 2012), are found in the northern Baffin Bay (Parnell et al., 2007).

Today, both warm Atlantic- and cold Arctic-sourced surface to subsurface waters access the marine margins of the GIS via deep cross-shelf troughs and fjords. The Arctic-sourced water that reaches Uummannaq Trough via the Baffin Current enters Baffin Bay from the Arctic Ocean through Nares Strait and channels between the Canadian Arctic Islands (Fig. 1A). Atlantic-sourced water originates from the Irminger Current and enters Baffin Bay from the south through Davis Strait via the West Greenland Current (WGC) (Dunlap and Tang, 2006; Münchow et al., 2015; Tang et al., 2004), forming the West Greenland Intermediate Water (WGIW) in Baffin Bay (Fig. 1A) (Tang et al., 2004). The Arctic Water mass occupies the upper $100-300 \mathrm{~m}$ of the water column below the locally-formed surface water, while the WGIW is usually found from 300-800 m water depth (Tang et al., 2004).

Sea ice in Baffin Bay is present nearly year-round; it begins to form in October in northern Baffin Bay, eventually expanding to cover all but the eastern Davis Strait by March. However, the extent and thickness of sea ice depends upon air temperature trends as well as the 
flowpath and strength of the WGC in any given year (Tang et al., 2004; Tang and Dunlap, 2007).

\section{Materials and Methods}

\section{Core locations}

Marine-sediment cores were collected on RRS James Clark Ross cruise JR175 in 2009 (Ó Cofaigh, 2009). Core locations were chosen based on high-resolution Topographic Parametric Sonar (TOPAS) sub-bottom profiles to allow the transition from basal till to overlying glacial marine sediments to be captured within the six metre coring limit of the vibrocorer system (Table 1). JR175-VC45 (hereafter VC45) on the outer shelf was taken from the top of a $10 \mathrm{~m}$ high moraine (Dowdeswell et al., 2014), and JR175-VC43 (hereafter VC43) was collected ca. $30 \mathrm{~km}$ east on the surface of a mega-scale glacial lineation (MSGL - Clark et al., 2003) where the upper drape of sediments was thin (Fig. 2). Both of these core sites map within acoustic Facies D (conformable sediment drape of glacimarine to hemipelagic origin) of Dowdeswell et al. (2014). In VC45, a radiocarbon date of $14.9 \mathrm{cal}$ kyr BP in glacimarine sediments $5 \mathrm{~cm}$ above the basal diamicton, interpreted as a till, indicates that ice retreat from the outer shelf was underway by this time (Dowdeswell et al., 2014; Ó Cofaigh et al., 2013a). JR175-VC42 (hereafter VC42) was taken within Facies S (acoustically stratified glacial marine to hemipelagic sediment drape) of Dowdeswell et al. (2014), from a site east of the GZW on the middle shelf (Fig. 1B and 2A) and just north of the transect line represented in Fig. 2A, c. 30 km east of core MSM343520 (Fig. 1), also from Facies S. At the site of VC42, the contact between the till and the overlying glacial marine sequence was sampled. Figure 2 shows that the postglacial drape of glacimarine sediments is thicker at the site where MSM343520, a 10 
m-long core, was taken (McCarthy, 2011). These two cores together capture the full section from till through postglacial sediments east of the GZW in the trough.

The cores were split in half longitudinally and visually described aboard the ship. All cores were later x-radiographed to allow more detailed description of the lithofacies. VC45, VC43 and VC42 end within basal unstratified diamicton.

\section{Radiocarbon dates}

Radiocarbon dates were obtained from mollusc shells and mixed or single-species benthic foraminifera (Table 2). Most samples were prepared at the Laboratory for AMS Radiocarbon Preparation and Research (NSRL) at the Institute of Arctic, Antarctic and Alpine Research (INSTAAR), and most radiocarbon samples were measured at the Keck AMS facility at the University of California at Irvine. Only sample AA-89913 was analysed at the University of Arizona Accelerator Mass Spectrometer (TAMS); this sample was previously reported in Ó Cofaigh et al., 2013b. All radiocarbon dates were calibrated using the CALIB Radiocarbon Calibration Program, version 7.1 (Stuiver et al., 2005) with the Marine13 dataset (Reimer et al., 2013). A $\Delta \mathrm{R}$ of $140 \pm 30$ years was used following the method described in the supplemental information for Lloyd et al. (2011). The calibrated ages (Table 2) used here correspond to the median ages calculated by CALIB 7.1. For the deglaciation date from core MSM343520 (McCarthy, 2011), the radiocarbon age was recalibrated using the same dataset and $\Delta \mathrm{R}$ described above. We stress that not all previous studies from Baffin Bay have applied the $\Delta \mathrm{R}$ of $140 \pm 30 \mathrm{yr}$ and in reality the $\Delta \mathrm{R}$ for MIS 2 in Baffin Bay is unknown. Calibrated ages are rounded to one decimal point.

\section{Lithofacies}


The lithofacies for VC42, VC43 and VC45 were determined by combining data from visual core descriptions and foraminiferal assays from small samples sieved and examined in the field, and $\mathrm{x}$-radiography. Clasts $>2 \mathrm{~mm}$ counted on the $\mathrm{x}$-radiographs (Grobe, 1987) were used as a proxy for IRD in lithofacies interpreted as marine and glacimarine in origin. Sediment colour, texture and sedimentary structures (e.g. laminations, bioturbation) were key features used to determine lithofacies. Shear strength was measured using a Torvane immediately after core splitting at $\sim 10 \mathrm{~cm}$ intervals as allowed by lithofacies boundaries.

\section{Mineralogy}

Quantitative x-ray diffraction (qXRD) analyses were used to determine the mineral composition of the sediments and to identify changes in sediment sources in lithofacies and through time. Samples for qXRD analysis were taken at 10 to $20 \mathrm{~cm}$ intervals, with fewer samples toward the base of the core. Sediment samples were freeze-dried and processed at INSTAAR using the method described by Eberl (2003) and Andrews and Eberl (2011). The qXRD samples were analysed on a Siemens D5000 XRD unit at a 0.02 2- $\theta$ step with a 2 second count, which resulted in 3000 data points; minerals were identified using the program RockJock v.6 (Eberl, 2003).

One hundred and thirty samples (including replicates) were processed for qXRD from VC42, VC43, and VC45. The approach has been used extensively for descriptions of sediment mineralogy on the West Greenland shelf and slope (Andrews et al., 2015; Andrews and Eberl, 2011; Ó Cofaigh et al., 2013a). For this study we reduced the identified minerals from an initial number of 34 down to 25 by eliminating minerals that had wt $\%$ estimates $\leq 1 \%$. The qXRD data were subjected to a fuzzy mean analysis, using the k-means clustering procedure 
in the program "FuzMe" to define mineral facies (Granath, 1984; Misnasny and McBratney, 2002). The exponent in the algorithm was set at 1.5 (a value of 1 results in a "hard" cluster). The fuzzy mean results were subsequently analysed using a Principal Component Analysis, which was also obtained as output from "FuzMe".

\section{Foraminiferal Analyses}

Samples for foraminiferal analyses were approximately $6 \mathrm{ml}$ in volume and taken at the same depth intervals as the qXRD samples. Subsamples from VC45 and VC42 were never dried. They were wet-sieved at 63 and $500 \mu \mathrm{m}$ and kept in a buffered solution composed of baking soda, ethanol and water with a target $\mathrm{pH}$ range of 8.0-8.4 to preserve the calcareous and agglutinated foraminifera (cf. Lloyd et al., 2005). The use of wet samples for foraminiferal assemblage analysis was advocated by Scott and Vilks (1991) to preserve small and delicate agglutinated and calcareous species that can otherwise be disaggregated and broken when samples are dried and then re-wetted during sieving. This method has been used in previous palaeoenvironmental and modern studies in Disko Bugt (Lloyd, 2006a, 2006b; Perner et al., 2013) and Uummannaq Trough (McCarthy, 2011), allowing for good comparisons with the fauna reported herein. The $>63 \mu \mathrm{m}$ fraction was analysed. Two hundred foraminifers were counted, where possible, to achieve reasonable counting statistics. A wet sample splitter was used to split the samples. Calcareous and agglutinated faunas were combined in assemblage analyses. Linings and hubs of calcareous taxa, which are remnants of dissolved calcareous foraminifera, were counted and tallied. Percentages were calculated for samples with at least 25 specimens. Foraminiferal concentrations were calculated as number of individuals per millilitre of bulk sediment. For VC43, small ( $<1.8 \mathrm{~g})$ freeze-dried samples that remained from the original qXRD samples were wet sieved at $63 \mu \mathrm{m}$ and foraminifera were tallied. The 
foraminiferal data were used for correlation purposes between VC45 and VC43 so that their radiocarbon dates could be shared.

\section{Results and palaeoenvironmetal interpretation}

\section{Lithofacies Description}

Six lithofacies were identified in the cores (Fig. 3). The lithofacies for MSM343520 were inferred from descriptions of the sediment given by McCarthy (2011) and are used for correlation and comparison with VC42. Examples of the lithofacies found in the cores are illustrated in Figure 3, while the down-core distributions of lithofacies are shown in Figures 4, 5 and 6. A description of each lithofacies and its interpretation is provided below.

Lithofacies L1: Massive diamicton. L1, the basal unit of VC45, VC43 and VC42, is massive, matrix-supported diamicton, barren of foraminifera. L1 is dark grey (5Y 4/1, VC45) to very dark grey (5Y 3/1, VC43 and VC42). Abundant subangular to subrounded clasts ranging from granule to pebble size are dispersed in a silty-mud (VC45) or sandy-mud (VC43 and VC42) matrix. Occasional inclined planar discontinuities are visible within the diamicton (e.g., VC42 $415-430 \mathrm{~cm}$ depth). The shear strength of this facies is variable, ranging from $0-25 \mathrm{kPa}$ in VC42 and 2-5 kPa in VC43.

Interpretation: Lithofacies L1. By its stratigraphic context at the base of cores VC45, VC43, and VC42, where the coring target was the subglacial to glacimarine contact (Fig. 2A) we anticipated that the basal unit of the cores would represent subglacial till. Indeed, L1 in VC45 is interpreted as till in previous work (Dowdeswell et al., 2014; Ó Cofaigh et al., 2013a). We interpret L1 as subglacial till in all three cores based on its stratigraphic position and its 
acoustic and physical characteristics which are similar to subglacial sediments interpreted elsewhere (Jennings, 1993; Ó Cofaigh et al., 2013b; Principato et al., 2005).

Lithofacies L2: Massive Pebbly Mud. L2 is massive dark grey (5Y 4/1, VC45) to very dark grey (5Y 3/1, VC43; 2.5Y 3/1, VC42) pebbly mud, sometimes bioturbated and characterized by dispersed angular to subangular granule- to pebble-sized clasts (Fig. 3). L2 is the first facies above L1 in both VC45 and VC43, and it also occurs again higher in both cores. In VC42 L2 is well developed much higher is the stratigraphy.

Interpretation: L2 sediments represent glacimarine conditions, where calving results in moderate to high concentrations of IRD, but where stratification related to turbid meltwater plumes is not evident.

Lithofacies L3: Crudely-stratified mud. This lithofacies only occurs in VC43. L3 sediments are dark grey to very dark grey ( $5 Y$ 4/1, 5Y 3/1, VC43) silty mud with subtle stratification formed by grain-size variations of the matrix. Coarser strata are 3 to $4 \mathrm{~cm}$ thick whereas finer strata are 4 to $10 \mathrm{~cm}$ thick. The faint stratification is partly disrupted by vertical burrows (Fig. 3D). Relatively low numbers of angular to subangular granule to pebble sized clasts are dispersed without regard to the stratification of the matrix.

Interpretation: L3 is interpreted to represent glacimarine conditions in which deposition of suspended sediments from turbid meltwater plumes is a dominant process (cf. Dowdeswell et al., 2015; Mugford and Dowdeswell, 2011; Powell, 1990). Thick fine-grained strata with vertical burrows suggest rapid sedimentation from suspension that would dilute the contribution of coarser clasts from iceberg rafting (cf. Syvitski, 1989). 
Lithofacies L4: Laminated mud. This lithofacies occurs only in VC42. L4 is very dark grey (2.5Y 3/1) mud with fine laminations between silty mud and sandy mud. Thin sand layers have sharp basal contacts. Laminations range from 0.1-1.5 $\mathrm{cm}$ in thickness. Dispersed angular to subangular clasts are distributed without regard to the laminations. Bioturbation is evident only at the top of the unit (Fig. 3E). Faulting in the laminae occurs in one interval (Fig. 3E). L4 is devoid of bioturbation except at the top of the unit and is barren of foraminifera. Interpretation: The well-preserved laminations, dispersed IRD and lack of bioturbation are consistent with suspended sediment deposition from turbid meltwater plumes occurring rapidly enough to preclude biological activity (Ó Cofaigh and Dowdeswell, 2001). Thin sand layers with sharp basal contacts may reflect deposition from turbidity currents released by failure of rapidly deposited unstable sediments or potentially from turbid meltwater released at the ice front. The sediment characteristics are consistent with Acoustic Facies S, which is characterized by strongly stratified glacimarine sediments near the till-glacimarine boundary, reflecting ice proximal conditions.

Lithofacies L5: Stratified pebbly mud. This dark grey (2.5Y 3/1) lithofacies occurs in VC43 and VC42. It is best expressed in VC42 where it overlies L1 (subglacial till) with a gradational contact. Mud layers with dispersed $>2 \mathrm{~mm}$ clasts and much coarser clast-rich layers form couplets that range from $1.5-4 \mathrm{~cm}$ thick. No bioturbation was observed. The mud layers contain coarser material and IRD. L5 is barren of foraminifera except in its upper occurrence in VC42.

Interpretation: L5 falls along a continuum with L4 in terms of its stratification. These two lithofacies reflect variations in the dominance of ice rafting and deposition of sediments suspended in turbid meltwater plumes. We interpret this lithofacies to reflect a greater 
contribution of sediments from iceberg rafting than from turbid meltwater plumes. In the case of L5 overlying L4, this progression would reflect relatively greater distance from a marine terminating ice front (cf. Syvitski, 1989). The coarse to fine strata may reflect a version of 'glacimarine varves' as described by Cowan et al. (1997) from southern Alaskan fjords in which coarse layers are deposited in winter when meltwater plumes cease and icebergs release debris, and finer layers with IRD are deposited in the summer melt season. This couplet-forming scenario differs from that proposed for sites off East Greenland (Dowdeswell et al., 2000; Jennings and Weiner, 1996). Off East Greenland, fine mud layers are thought to represent extremely cold conditions in which sea ice cover precludes transit of icebergs through the fjord and fine material is deposited from suspension, whereas coarse layers represent warmer conditions in which icebergs are freely transiting the fjord. However, in the present case, it represents a calving environment within the shelf trough. Because the fine layers in L5 contain sand and coarser material it seems more likely that these layers represent relatively warm conditions when meltwater plumes are active. The coarse layers likely represent periods of low turbid plume release from the ice front. L5 in VC42 is similar to the stratified diamicton reported from inner Disko Trough by Hogan et al. (this issue).

Lithofacies L6 is dark grey (5Y 4/1, VC45 and VC43) or dark olive grey (5Y 3/2, VC42) bioturbated silty mud that forms the core-top sediments in the three cores. L6 sediments generally contain low numbers of $>2 \mathrm{~mm}$ clasts and are strongly bioturbated. Interpretation: The L6 sediments show little to no ice-rafting activity indicating very distal glacier margins. The heavy bioturbation indicates relatively slow sedimentation rates. L6 represents environments with little glacier influence, similar to those of today. 


\section{qXRD: Mineral Composition and Fuzzy Mean Clusters}

Our working qualitative model suggests that, as the Uummannaq ice stream retreated from the shelf break towards the present coastline, erosion of the underlying bedrock would be recorded in the mineralogy of ice-rafted and glacial meltwater-transported sediments (Fig. 1c). In order to assess this model we need to establish if there are distinct "mineral facies," (MF) here defined as intervals of similar mineral composition. The fuzzy k-mean clustering procedure (Granath, 1984; Misnasny and McBratney, 2002) was used to define mineral facies, thus allowing for qXRD method estimation errors (Andrews and Vogt, 2014). The evaluation criteria for the most appropriate number of clusters/MF (Minasny and McBratney, 2002) indicated 2 distinct clusters for the qXRD dataset. The mineralogy clearly indicates that the MF for VC45 and VC43 are very similar, while VC42 differs in the dominant MF and records more down-core variability (Fig. 4A).

To illustrate the range in MF we plot scores on the $1^{\text {st }}$ Principal Component (PC1) (Davis, 1986) for a) the three cores, and b) for the two MF solution (Fig. 4A and B). The results indicate that the PC1 scores on VC42 are, on average, distinct from those in VC43 and VC45 (4A). Furthermore, VC43 and VC45 are nearly exclusively in MF 2a (only 1 and 3 samples, respectively, from these two cores are not grouped in MF 2a), whereas VC42 contains significant samples of both 2a and 2b MFs (Figs. 4-7). Discriminant Function Analysis (DFA) (Davis, 1986) indicated that the $2 \mathrm{MF}$ clusters correctly classified samples, with $<5 \%$ mismatches. Figures 4C and 4D show box plots of selected minerals important for defining the two mineral facies and how these are represented overall within each of the 3 cores. VC43 and VC45 have similar wt \% mineral distributions, whereas VC42 is distinguished by higher 
values of albite and oligoclase feldspars, two of the sodium-rich plagioclase feldspars (Figure 4D). Given the location of VC42 close to the limits of Cretaceous sediments and early Tertiary basaltic outcrops (Chalmers et al., 1999; Pedersen and Pulvertaft, 1992), we were surprised that the sediments had much lower wt $\%$ of minerals that are associated with these outcrops, such as pyroxene, kaolinite, and smectite (saponite) (Andrews et al., 2015). On the outer shelf above the basal diamicton, the sediments are dominated by MF 2a. In VC45, the few samples directly above its basal diamicton also had a small but consistent component of MF $2 \mathrm{~b}$. The basal diamicton (=till) in VC43 is the only part of that core with significant component of MF 2b. The basal diamicton unit of VC42, L1, was dominated by MF 2b, while MF 2a comes in as a strong but variable contribution above the basal diamicton. MF 2a therefore represents minerals more strongly associated with the fjords, and MF $2 \mathrm{~b}$ represents minerals more strongly associated with shelf sediments.

\section{Sediment Stratigraphy}

\section{Sediments of VC45, outer shelf}

The basal diamicton, subglacial till unit, L1 (141-133 cm) in VC45 (Fig. 5) was so pebbly and thin that no shear vane measurements and no foraminiferal or qXRD samples were taken. L1 is overlain by L2, massive pebbly mud $(133-100 \mathrm{~cm})$ with a diffuse contact (Fig. 3). The basal $4 \mathrm{~cm}$ of L2 are very pebbly and have up to 0.2 membership in MF $2 \mathrm{~b}$. From 129 to $120 \mathrm{~cm}$ the massive pebbly mud has low IRD counts and faunal abundance. However, above $120 \mathrm{~cm}$ there is increasing IRD, bioturbation, and foraminifera. Above the basal $4 \mathrm{~cm}$, L2 mineralogy is dominated by MF 2a. The radiocarbon date calibrated to 15.0 cal kyr BP (previously 14.9 cal kyr BP) was obtained on foraminifera at $125-127 \mathrm{~cm}$, below the interval of highest faunal 
abundance. Centred at $100 \mathrm{~cm}$ is a band of IRD containing brown intraclasts (Fig. 3). This unit coincides with a total carbonate (dolomite and calcite) peak of $21 \%$ that represents detrital carbonate (DC). The DC peak occurs between 110 and $95 \mathrm{~cm}$, increasing from a 1\% total carbonate background. The visual DC unit marks the top of L2. It is overlain by L6, bioturbated mud with low IRD counts. Dispersed IRD increases between 63-69 cm, but the unit overall has very little coarse IRD. The foraminiferal abundances are high at the base of the unit such that a date (13.9 cal kyr BP) was obtained on a single species of benthic foraminifera $5 \mathrm{~cm}$ above the DC peak. A pronounced rise in IRD between 38-16 $\mathrm{cm}$ marks the return to L2, massive pebbly mud. This unit is the last IRD-rich unit in the sequence on the outer shelf. It has some large burrows at the top but otherwise is massive. The transition at 16 cm from the pebbly mud (L2) to overlying bioturbated mud (L6) is sharp and disturbed by bioturbation indicating a much slower sedimentation rate in L6. The low IRD content and transition to greyish red $(2.5 \mathrm{Y} 4 / 2)$ at the top of the unit suggest it represents modern marine sedimentation in the outer Uummannaq Trough.

\section{Sediments of VC43, outer shelf}

L1 is the basal unit of VC43 (311-247 cm; Fig. 6). It is a soft, massive, matrix-supported diamicton interpreted to represent the subglacial environment of a MSGL formed beneath a fast-flowing ice stream that reached the outer shelf (cf. Dowdeswell et al., 2014; Ó Cofaigh et al., 2013b). The unit has weak vertical alignment and concentrated large clasts above $268 \mathrm{~cm}$. Shear strength values are low (3.5 to $5 \mathrm{kPa}$ ) and the unit is barren of foraminifera. Such weak massive diamictons have been documented within MSGLs on other polar continental shelves (e.g., Dowdeswell et al., 2004; Ó Cofaigh et al., 2005, 2007), where they have been interpreted 
as the product of deforming bed processes beneath fast-flowing ice streams. Aligned clasts and planar discontinuities represent zones of subglacial shear within the soft sediments (Ó Cofaigh et al., 2007). The mineralogy of L1 shows shared membership between MF 2a and 2b. Clast counts are assigned a value of 20 to indicate that they are high (saturated) and uniform (Fig. 5). L2, massive pebbly mud, overlies L1 $(247-228 \mathrm{~cm})$ with a sharp contact (Fig. 3). IRD increases upwards in L2. Bioturbation begins by $235 \mathrm{~cm}$. The unit has low foraminiferal content and is fully within MF 2a. A fairly thin unit of L5 $(228-207 \mathrm{~cm})$, stratified pebbly mud, abruptly overlies L2. The base of this IRD-rich unit is a $5 \mathrm{~cm}$ thick band of angular pebbles followed by alternating coarse and fine layers. L5 transitions to L3 $(207-164 \mathrm{~cm})$. In this unit the IRD is dispersed and the bands are formed from slightly coarsening matrix. Vertical burrows suggest rapid sedimentation (Fig 3) and the foraminiferal abundance increases. High faunal abundances continue into the overlying unit, L2, massive bioturbated pebbly mud $(164-115 \mathrm{~cm})$. IRD counts are high. Lithofacies L3 $(115-90 \mathrm{~cm})$ is best described as alternating bioturbated mud and IRD rich intervals. From $90-70 \mathrm{~cm}$ is a distinct interval of bioturbated mud with granules showing overall finer, bioturbated sediments with low foraminiferal content. A radiocarbon date from a gastropod from near the top of this interval gave an age of 11.5 cal kyr BP, suggesting the overlying boundary with L2 is post-Younger Dryas in age. The overlying unit of L2 $(70-10 \mathrm{~cm})$ is massive, bioturbated pebbly mud in which the IRD is fairly uniformly distributed. This is the last IRD-rich interval in the core. Foraminiferal abundance increases in this unit. The uppermost $10 \mathrm{~cm}$ of VC43, L6, comprises bioturbated mud with very rare dropstones. The boundary between L2 and L6 is disturbed by large burrows that bring L6 mud into underlying L2. This surface mixing and the very bioturbated nature of L6 suggest that it was deposited slowly, representing modern outer shelf sedimentation, but the timing of the transition to L6 is not constrained. 


\section{Sediments of VC42, mid shelf}

A thick unit of subglacial sediment, L1, forms the basal unit of VC42 (552-203 cm; Fig. 7). This massive, matrix supported diamicton includes rare large clasts up to $5 \mathrm{~cm}$ in diameter but more commonly clasts are closer to $0.5 \mathrm{~cm}$ diameter. The clasts were not counted directly, but rather represented by an arbitrary count of 20 , as the number of clasts was always high, fairly uniform, and essentially at the saturation of the method. The clasts in some intervals show vague vertical alignment and elsewhere there are planar discontinuities within the diamicton matrix visible on the x-radiographs. Shear strength values range from 20 to $25 \mathrm{kPa}$ in this unit. The weak matrix, planar discontinuities and generally massive structure are all consistent with an origin as subglacial till formed, at least in part, by deforming bed processes (Ó Cofaigh et al., 2007). A major shift in mineralogy coincides with the transition from subglacial L1 to glacimarine L5. MF 2b dominates L1 with limited variations. Above L1 the mineralogy is significantly more variable and the MF switch rapidly between MF 2a and 2b. L1 transitions gradually to L5, stratified pebbly mud (203-160 cm). L5 transitions abruptly to L4, laminated mud (160-127 cm) with a loss of coarse IRD and onset of fine laminations (0.1-1.5 cm laminations) with dispersed dominantly granule and smaller sized IRD. Faulting in the laminae is apparent between 140 and $150 \mathrm{~cm}$ (Fig. 3E). The top of the unit is bioturbated, largely destroying the evidence of laminae (Fig. 3E). Laminated mud transitions abruptly to stratified pebbly mud, L5 $(127-98 \mathrm{~cm})$ with a sudden increase in coarse IRD. L5 is clearly grain-size stratified with concentrations of coarse material alternating with mud containing dispersed IRD (Fig. 3F). The MF shows an increase in cluster 2a. Within this unit faunal abundance rises above barren for the first time. The transition from L5 to massive 
bioturbated mud, L2 $(98-45 \mathrm{~cm})$, occurs with the disappearance of the coarse strata. L2 is associated with rapid variations between MF $2 \mathrm{a}$ and $2 \mathrm{~b}$, and relatively consistent foraminiferal abundance. L2 is overlain by L5 $(45-14 \mathrm{~cm})$. The stratification is disrupted by bioturbation, suggesting a decreased sedimentation rate. The uppermost $14 \mathrm{~cm}$ is massive bioturbated mud with rare IRD, L6, which likely represents modern sedimentation at the site.

\section{Foraminifera}

Species groups

The foraminifera are here split into two main groups: "warmer" species that are often associated with Atlantic Water and "colder" species that are usually associated with Polar Water (Table 3). However, because Nares Strait and the Canadian Arctic Islands were blocked by ice sheets for most of the time period represented in our record, the Polar-derived water inferred from faunal assemblages must have entered Baffin Bay as part of the East Greenland Current component of the WGC or reflects glacial meltwater. Other significant environmental allocations are "productivity," i.e. species that are linked to habitats with increased food availability, and "meltwater," encompassing species that tolerate the unstable environments and low salinities associated with high glacial meltwater fluxes. Species that comprised less than $2 \%$ of the foraminiferal abundance were not included in the statistical analyses and were not considered important indicators of environmental conditions.

\section{Foraminiferal Stratigraphy}

A total of 40 foraminiferal species were identified in cores VC45, VC43 and VC42; 16 species were agglutinated and 24 species were calcareous. Only species comprising at least $5 \%$ of at 
least one sample in its respective core are plotted in the figures; all species included in the foraminiferal assemblage plots are shown, along with their general environmental preferences, in Table 3. In VC45 (Fig. 8), there is evidence of dissolution of calcareous foraminifera (hubs and linings) in all faunal zones except for zone F45-2 (see following section Foraminiferal zones). No foraminifera were expected or found in the till (L1) lithofacies in the cores.

The foraminiferal assemblages for VC43 (Fig. 9) were counted based on dried samples so linings were not preserved; most of the samples were too small to achieve the cut-off value of 25 foraminiferal specimens to constitute a "full" assemblage. The interval that contains sufficient foraminifera for assemblage analysis coincides with zones F45-1, F45-2 and F45-3. The main outer shelf core, VC45, has much higher foraminiferal abundances than the midshelf core, VC42.

In VC42 (Fig. 10), the pattern is similar, with more calcareous hubs toward the bottom of the core (F42-1 and the bottom of F42-2), and the highest numbers of calcareous linings in the top of the core, in F42-3.

The presence of calcareous hubs and linings in many samples indicates that there is some loss of calcareous foraminiferal tests by carbonate dissolution. Based on the morphology of the hubs and linings, we infer that the calcareous hubs are from Islandiella spp. or Cassidulina neoteretis, while the calcareous linings are likely from Elphidium excavatum f. clavata. They are used to infer presence of these calcareous species prior to dissolution. The hubs and linings comprise only a small percentage of the assemblage (Fig. 8, 10).

\section{Foraminiferal zones}


Constrained, minimum variance cluster analysis was run on square-root transformed faunal data to determine assemblage zones using the Multivariate Statistical Package (MVSP) (Kovach, 1998) for cores VC42 and VC45. Species included in the statistical analysis of the individual cores comprised at least $2 \%$ of at least one sample. Cluster analysis illustrates that the most distinct change in the foraminiferal assemblages of core VC45 is the transition from a calcareous-dominated assemblage in the lower half of the core to a fauna dominated by agglutinated taxa from $60 \mathrm{~cm}$ to the top of the core. A similar transition from calcareous to agglutinated assemblages also forms the most distinct zonal boundary in VC42. The assemblage of VC43 did not contain sufficient foraminifera to apply the cluster analysis technique; therefore no faunal zones were created for VC43. The sequence of faunal zones and their association with the sequence of lithofacies is shown in Figures 8 and 10, while the foraminiferal assemblages for VC43 are presented along with lithofacies in Figure 9. Faunal zone boundaries are placed at the midpoint between samples. They are labelled F45-1, F42-1, etc.

\section{Foraminifera in VC45, outer shelf}

VC45 was divided into four faunal zones (Fig. 8): Lithofacies L1 was determined to be barren of foraminifera by examination of the 'shoe', or core cutter material from the vibrocorer, when the core was collected.

Zone F45-1 (VC45: 133-122 cm) coincides with the lower IRD-rich part of L2 directly above the basal diamicton. The assemblage is calcareous and dominated by Elphidium excavatum $\mathrm{f}$. clavata and Cassidulina reniforme, indicative of glacimarine conditions, and Islandiella norcrossi, linked to chilled Atlantic Water (Table 3). Several species suggestive of relatively high marine productivity, Melonis barleeanus, Stainforthia concava and S. feylingi, occur in the 
deepest sample of this zone but are absent in the overlying two samples. This zone includes a sample dated to $15 \mathrm{cal}$ kyr BP, which provides a constraint on the timing of ice retreat from the outer shelf, although the presence of M. barleeanus, S. concava and I. norcrossi, especially in the deepest sample of this zone, is not indicative of ice-proximal conditions and that the earliest deglacial environments are not preserved at this site.

Zone F45-2 (VC45: 122-100 cm) corresponds to the upper unit of L2 that ends with the visible DC event. It includes the samples with the highest concentrations of foraminifers in the core. The zone is dominated by calcareous species, along with low percentages of the agglutinated species Spiroplectammina biformis. It differs from F45-1 in that the percentages of E. excavatum f. clavata decrease to low values and $C$. reniforme becomes the dominant species. I. norcrossi and S. feylingi are subdominant. The presence of Pullenia osloensis supports an interpretation of relatively high marine productivity early in this zone. Altogether the faunal composition is consistent with somewhat reduced glacial influence and increasing Atlantic Water influence on the outer shelf.

Zone F45-3 (VC45: 100-60 cm) occurs entirely within L6 sediment. In this zone, E. excavatum f. clavata disappears from the assemblage and C. reniforme becomes subdominant to $I$. norcrossi and S. feylingi. C. neoteretis, a strong indicator of Atlantic Water influx, enters the assemblages in this zone along with Melonis barleeanus, a species that reflects stable marine productivity or buried food. Several agglutinated species occur in this zone including $S$. biformis and Textularia torquata. P. bipolaris enters the assemblage for the first time in the top of this faunal zone. The presence of calcareous hubs (generally reflecting corroded Islandiella helenae, I.norcrossi or C. neoteretis) and linings (representing dissolved E. excavatum $\mathrm{f}$. clavata) indicate some loss of specimens to dissolution, but the faunal abundances are still 
reasonably high. A radiocarbon date of 13.9 cal kyr BP was acquired from I. norcrossi near the base of this zone. Overall the faunal characteristics of this zone suggest continued decrease in glacial influence and relative increased influence of Atlantic Water in the environment (WGC) by 13.9 cal kyr BP.

Zone F45-4 (VC45: 60-0 cm) covers the transition from L6 to L2 and back to L6 sediments. This zone marks the transition to a largely agglutinated fauna with calcareous linings, suggesting poor preservation of calcareous tests and overall low faunal abundances. The dominant agglutinated species are P. bipolaris and T. torquata, both of which are Arctic species common in the shelf and fjord areas of East and West Greenland today, and are in general indifferent to the temperature and salinity of water masses (McCarthy, 2011). Other than Bovinellina pseudopunctata, a calcareous species indicative of high productivity, there are very low numbers of calcareous specimens, although the presence of calcareous linings suggests that some of the calcareous assemblage was lost to dissolution. A frequent observation from Disko Bugt and Disko Trough cores is linings emerging from corrosion of $E$. excavatum f. clavata tests (cf. Jennings et al., 2014). It is likely that the intervals of calcareous linings in F45-4 represent periods of presence of E. excavatum f. clavata. The assemblage composition of this zone is consistent with cooling and decreased Atlantic Water influence.

\section{Foraminifera in VC43, outer shelf}

VC43 foraminiferal assemblages were completed on small dried samples in an effort to see if the fauna could provide correlation points so that the radiocarbon dates could be shared in the two outer shelf cores. Samples from VC43, having been dried, would be expected to have fewer of the fragile calcareous species such as Stetsonia horvathi and Stainforthia feylingi as 
well as fewer agglutinated taxa. In addition, calcareous linings are not preserved in dried samples.

VC43 is barren of foraminifers from the basal diamicton, L1, through L5 $(311-207 \mathrm{~cm})$. Within the overlying lithofacies, L3 and L2 the foraminiferal abundances rise and allow percentage calculations. Assemblages over this interval begin with dominant E. excavatum f. clavata and then shift to an assemblage dominated by C. reniforme and I. norcrossi but still containing $E$. excavatum f. clavata. These shifts match well the main composition of F45-1 and F45-2 (VC45), except that S. feylingi is very rare in the VC43 assemblages. This lack of S. feylingi likely is a consequence of analysing dried samples. Based on the faunal comparisons and the lithostratigraphy, we place the $15.0 \mathrm{cal} \mathrm{kyr} \mathrm{BP} \mathrm{age} \mathrm{in} \mathrm{VC45} \mathrm{at} 200 \mathrm{~cm}$ in VC43 (Fig. 9). C. neoteretis and S. biformis enter the VC43 assemblage at $165 \mathrm{~cm}$. This faunal shift is similar to that which occurs between F45-2 and F45-3 in VC45. On this basis we tie these cores together and assign an age of $13.9 \mathrm{cal}$ kyr BP to $\sim 165 \mathrm{~cm}$ in VC43 (Fig. 9).

VC43 has a radiocarbon date of $11.5 \mathrm{cal}$ kyr BP at $72 \mathrm{~cm}$, immediately below the contact between L6 and L2 (Fig. 6). The increase in IRD marked by L2 is the last IRD event recorded on the outer shelf. The unit is overlain by L6 assumed to represent postglacial to modern conditions. Based on the foraminiferal assemblages, this last IRD rise in VC43 likely corresponds to the similar rise in IRD in VC45, which also has a sequence of L2 to L6 at the core top, but has no associated dates. This correlation of lithofacies and foraminiferal assemblages is possible due to the close geographical proximity of the two cores (VC43 is $\sim 35$ $\mathrm{km}$ east of VC45). Above the L6 interval, VC43 has a further succession of calcareous foraminiferal faunas not seen in VC45, so this section cannot easily be correlated between the 
cores. Most conservatively, the tie point from VC43 to VC45 would occur between the first occurrence of Portatrochammina bipolaris (65 $\mathrm{cm}$ in VC45) and the first occurrence of Textularia earlandi (20 $\mathrm{cm}$ in VC45). This is a very wide interval that precedes and postdates the beginning of L2 in VC45 and encompasses the final rise in IRD. We argue that the date of 11.5 cal kyr BP from VC43 falls within this range in VC45. In addition, the coincidence of $E$. excavatum f. clavata in VC43 in samples at 60, 50 and $40 \mathrm{~cm}$, above the $11.5 \mathrm{cal} \mathrm{kyr}$ BP date and the presence of calcareous linings within the last IRD event in VC45 (at 30 and $20 \mathrm{~cm}$ ) that most likely come from E. excavatum f. clavata, provide additional evidence for correlation between the two cores. On this basis we infer that the increase in IRD coinciding with the lithofacies shift from L6 to L2 is the same event in both cores and dates to post Younger Dryas (c. 11.5 cal kyr BP).

Foraminifera in VC42, mid shelf

VC42 was divided into three faunal zones. The core was barren from L1, subglacial till through the lowermost glacial marine lithofacies (L5) until $156 \mathrm{~cm}$, where very low numbers of $S$. biformis and C. reniforme appear in the laminated mud of L4. These samples had too few foraminifera to calculate percentages. The first sample with a statistical count is at $115.5 \mathrm{~cm}$, within L5, stratified pebbly mud.

Zone F42-1 (VC42: 116-85 cm) straddles the upper part of unit L5 and the lower part of L2. This faunal zone is dominated by calcareous foraminifera, but also contains some relatively common agglutinated taxa. The most abundant species included S. horvathi, C. reniforme, $S$. feylingi, C. neoteretis, S. biformis, P. bipolaris and D. grahami. The species assemblage is 
diversely associated with episodic productivity, meltwater, sea ice cover, and chilled Atlantic water, suggesting a subsurface Atlantic water influence on the retreating ice margin.

Zone F42-2 (VC42; 85-45 cm) straddles the transition from L2 to L5 sediment. The zone is dominated by agglutinated foraminifera. The most abundant species are $S$. biformis and $P$. bipolaris which suggest cold conditions as these two species are also co-dominant in Mikis Fjord, a meltwater-influenced, Polar water dominated fjord on East Greenland (Jennings and Helgadottir, 1994). Other agglutinated species, C. crassimargo, Cuneata arctica, Reophax fusiformis and Textularia torquata occur in lower percentages. The zone also has low percentages of S. feylingi and S. concava, which are often found in connection with high productivity events. The dominance of $S$. biformis is consistent with dominance of polar water and/or meltwater, rapid sedimentation and ice-distal glacimarine conditions.

Zone F42-3 (VC42: 45-0 cm) covers the transition between L5 to L6 sediment at the top of the core. This zone is dominated by agglutinated taxa and calcareous linings. The most abundant species are S. biformis and T. torquata. Subsidiary species include P. bipolaris, $C$. crassimargo, C. arctica, A. glomerata and T. earlandi. The agglutinated foraminifera show a mixture of colder-water (Polar) and warmer water (Atlantic) influence, and some productivity (S. feylingi). Common calcareous linings indicate that E. excavatum f. clavata was originally common in this zone, consistent with cooling and reduced salinity. The zone represents waning of glacimarine environment and onset of modern conditions on the shelf (McCarthy, 2011). 
Core VC42 captures the ice retreat from the middle shelf GZW making it an important record for glacial history. Unfortunately, no radiocarbon dates were obtained from this core. We have, however, taken advantage of a well-dated core that was collected approximately $32 \mathrm{~km}$ west in Uummannaq Trough, MSM343520 (Fig. 1b) (McCarthy, 2011). Core MSM343520 ends within glacimarine sediments and has a high-resolution Holocene record, whereas VC42 sampled the till and ice-proximal glacimarine section and has a truncated Holocene record. Combined, these two cores provide a full sediment record representing subglacial to postglacial marine conditions through the Holocene. The faunal assemblages from the two cores were compared to determine where the sedimentary records overlap and to find a tie point in VC42 for the deepest date in MSM343520, which constrains deglaciation (McCarthy, 2011). The appearance of the agglutinated foraminiferal species C. arctica in VC42 occurs in zone F42-2 at approximately $70 \mathrm{~cm}$ (Fig. 10), while the first appearance of this species in core MSM343520 is found at the top of faunal zone FAZ1b (McCarthy, 2011). The abundance pattern of this species is similar in both cores, with abundances increasing upward in their respective zones. In MSM343520, this interval was dated to 10.9 cal kyr BP (recalibrated to $10.8 \mathrm{cal}$ kyr BP using the Marine13 dataset and $\Delta \mathrm{R}$ described in Methods). We therefore assign $70 \mathrm{~cm}$ in VC42 the age of $10.8 \mathrm{cal}$ kyr BP (Fig. 10) that comes from the top of FAZ1b in MSM343520 (McCarthy, 2011).

\section{Discussion}

\section{Retreat from the outer shelf to the mid shelf GZW (VC45)}

Core VC45 was taken from a moraine ridge in the outermost trough, which is considered to mark the terminus of the Uummannaq Ice Stream at the Last Glacial Maximum (Ó Cofaigh et al., 2013b; Dowdeswell et al., 2014). The earliest date of deglacial sediments taken from VC45 was calibrated to $15.0 \mathrm{cal}$ kyr BP; however, the lithological sequence suggests that the full 
deglaciation sequence was not captured. Rather, glacimarine sediments and foraminiferal faunas with both Atlantic and Polar water associated species, and the absence of typical iceproximal foraminiferal faunas (cf. Steinsund, 1994), indicate that deglaciation occurred prior to $15.0 \mathrm{cal}$ kyr BP. The sediments containing this assemblage were first assigned to the till (Ó Cofaigh, et al., 2013b), but based on the faunal content they are now considered to be a condensed unit, or lag deposit, representing a time period after ice retreat and prior to $15 \mathrm{cal}$ kyr BP. The mineralogy of this thin, IRD-rich unit indicates the presence of subglacial erosion products and therefore glacial ice influence. The MF $2 \mathrm{~b}$ membership is consistent with its stratigraphic position above till and supports its provenance as a condensed unit representing, in part, residual sediments reflecting earlier, more ice-proximal conditions. Above the condensed unit is pebbly mud, which initially contains a thin interval with a glacimarine faunal signal dated to $15.0 \mathrm{cal}$ kyr BP (F45-1). The dates indicate that only $32 \mathrm{~cm}$ of sediment were deposited in 1000 years in what is stratigraphically the most ice-proximal unit of this core. The bioturbation, diminishing glacial influence on the fauna, and lack of stratification suggest that these sediments were deposited increasingly distal to the ice margin. Low resolution sediment records of deglaciation from the outer shelves relative to the rapid sedimentation and meltwater-influenced record of the inner shelves is a common pattern around Greenland and reflects the presence of bathymetric deepening toward the land. The deepening forms sediment traps, differing from the outer shelf conditions where there is greater exposure to currents, wave action, and reworking by deep-keeled icebergs (cf. Dowdeswell et al., 2010; Evans et al., 2009; Gilbert et al., 1998; Jennings et al., 2002, 2013).

The significant differences seen in the early records of the outer shelf cores may reflect a more complete deglacial sequence in VC43 than is found in VC45. The full deglacial sequence 
includes evidence of meltwater and rapid sedimentation soon after deglaciation. The sediments directly overlying the till represent, stratigraphically, the most ice-proximal conditions in VC43 (cf. Hogan et al., 2012): this interval is barren of foraminifera, but contains abundant sand-sized diatoms (cf. Coscinodiscus oculus-iridis) indicating cold sea-surface temperatures (Arto Miettinen, personal comm., 2014).

The faunal sequences in VC45 and VC43 are similar beginning at the 15.0 cal kyr BP tie-point (Fig. 8, 9). At ca. 15 cal kyr BP, both cores show assemblages dominated by glacimarine species (F45-1) that transition to faunas reflecting increasing Atlantic water influence and decreasing glacial influence between 15 and 13.9 cal kyr BP (F45-2). The DC layer, ca. 14 cal kyr BP, tops the pebbly mud and supports a distal glacimarine environment, with icebergs sourced from both Greenland and northern Baffin Bay (cf. Jennings et al., 2014).

Directly overlying the DC layer, a unit of bioturbated mud encompasses a foraminiferal assemblage showing the least glacimarine influence and the greatest faunal association with Atlantic Water (F45-3, dated to ca. 13.9 cal kyr BP) in the core. The lithology suggests diminished iceberg drift to this area from both Greenland and northern Baffin Bay ice margins. In VC43, $35 \mathrm{~km}$ landward into the trough, an Atlantic Water fauna, including $C$. neoteretis, is also present, but is here associated with IRD-bearing mud. Dominant Atlantic water fauna suggest that the WGC was established on the outer shelf by 13.9 cal kyr BP. Although there are insufficient data to conclude that the WGC played a strong role in initiating the ice-stream retreat (cf. Knutz et al., 2011), it is likely that the warm current helped to sustain the ice retreat, as has been observed along modern marine Greenland ice sheet margins (Holland et al., 2008; Straneo et al., 2010, 2011). 
After the maximum occurrence of Atlantic fauna (F45-3), a general cooling on the shelf is indicated by a shift to very low faunal abundances, dominated by agglutinated taxa with Arctic associations (F45-4, Fig. 8, Table 3). Similarly in VC43, the Atlantic fauna ends in a barren interval. Both cores show barren or nearly barren faunal intervals with low counts of IRD followed by the IRD events, interpreted as a still-stand or a possible re-advance of the ice followed by rapid retreat.

The start of the upper IRD event in VC43 is dated to 11.5 cal kyr BP; we infer that this shift occurred at the same time as did the upper IRD event in VC45. The timing of this interval suggests that the IRD event coincided with the end of the Younger Dryas. Although not dated specifically, the conditions leading up to the deposition of the IRD probably coincide with the cooling and onset of more unstable conditions during the Younger Dryas chron recorded around the North Atlantic (cf. Bakke et al., 2009; Jennings et al., 2006, 2014; Murton et al., 2010; Pearce et al., 2014). Within the last IRD event, foraminiferal faunas indicating warmer water and high productivity (Fig. 8 and 9) are present in both outer shelf cores, suggesting that Atlantic-sourced water was present and possibly helped to speed up the ice retreat across the inner shelf (cf. Bindschadler, 2006).

\section{Significance of Detrital Carbonate in VC45}

The DC layer in VC45 is of interest because its mineralogy reflects an origin outside of the Uummannaq Trough. Based on its colour and mineralogy, the DC layer matches a northern Baffin Bay provenance (Andrews and Eberl, 2011). Multiple detrital carbonate layers rich in dolomite have been documented in late Quaternary sediments from Baffin Bay (Andrews et 
al., 1998; Simon et al., 2012). The youngest of these layers, BBDC1 and BBDC2, are dated in Baffin Bay to ca. 10.5 to $12 \mathrm{kyr}$ and ca. 15.5 to $13.5 \mathrm{kyr}$, respectively (Simon et al., 2012). The chronology of VC45 suggests that the DC layer in this core matches the end of BBDC2. There were no BBDC units found in VC43 or in core HE006-04-02 (Fig. 1B), located further north along the Uummannaq Trough mouth fan. Jennings et al. (2013) noted a DC layer on the central West Greenland slope dated between 14.4 and 13.9 cal kyr BP, where it is interpreted to reflect enhanced melting of northern Baffin Bay icebergs as they came in contact with the WGC. The northernmost core that contains a likely BBDC layer is JR175-VC46, located on the upper slope of the Uummannaq Trough (Fig. 1B). The presence (VC45, VC46) or absence (HE006-4-2, VC43) of the DC event delineates the northern- and easternmost distribution of IRD for this DC event, which also marks the boundary between the northward-flowing WGC and colder surface conditions of northern and western Baffin Bay. This interpretation is consistent with the presence of Atlantic-associated fauna in core VC45 and suggests that the DC layer provides an independent marker of the presence of the WGC on the shelf. Previously, the earliest evidence of the subsurface influence of the WGC in Baffin Bay was from foraminiferal fauna recorded in northern Baffin Bay at 10.9 cal kyr BP (Knudsen et al., 2008).

\section{Retreat from mid shelf grounding-zone wedge (VC42)}

VC42 provides a record of ice retreat from the mid-shelf GZW. Instead of the thin glacimarine sequence of the outer shelf, the mid-shelf has a distinct stratified to massive sequence that reflects the combined influence of turbid meltwater plumes and ice-rafting processes during ice retreat (Fig. 7) (cf. Hogan et al., 2012). Rapid fluctuations between the mineral facies in VC42 (Fig 10) occur in the ca. $2 \mathrm{~m}$ thick glacimarine sequence. Such variability is not present 
in VC45 and VC43 on the outer shelf, which underscores the limited preservation or deposition of ice-proximal sediments in the outer shelf cores (cf. Jennings et al., 2002).

The first quantifiable fauna present in VC42 occurs in stratified pebbly mud. This lithofacies has similarities to ice-proximal glacimarine units in Disenchantment Bay, Alaska (Ullrich et al., 2009), which have been interpreted to represent winter-deposited diamicton, summer meltwater plumes, and iceberg rafting deposits. The foraminiferal assemblages in this interval are consistent with a strong meltwater signal and a subflow of chilled Atlantic Water (WGC).

While VC42 did not contain sufficient carbonate material for radiocarbon dating, its inferred tie point with MSM343520 provides a minimum deglacial date of 10.8 cal kyr BP. The tie point with MSM343520 (Fig. 7) lies $1.5 \mathrm{~m}$ above the till, within distal glacimarine, massive pebbly mud that contains a strong meltwater faunal signal. This date indicates that ice had retreated from the mid-shelf GZW and was east of both MSM343520 and VC42 by 10.8 cal kyr BP; therefore, the initial retreat from the mid-shelf GZW must have been earlier (cf. Lane et al., 2014). We infer that the ice retreat recorded in VC42 corresponds to the last IRD event recorded in the outer shelf cores, beginning at the end of the Younger Dryas chron, ca. 11.5 cal kyr BP.

\section{Retreat dynamics of Uummannaq Ice Stream on the shelf}

Previous work has shown that ice sheet outlets filled the fjords in the Uummannaq system, and extended to the shelf break as a confluent ice stream (Dowdeswell et al., 2014; Lane et al., 2014; Ó Cofaigh et al., 2013b, 2013b; Roberts et al., 2013). Based on the constraining age in VC45, ice retreat from the outer shelf was underway by 15.0 cal kyr BP. The occurrence of 
"warm water" foraminifera soon after the proximal glacial sediments in all three cores suggests that the WGC was present on the shelf soon after the initial deglaciation of the outer shelf, as well after the Younger Dryas ice retreat from the GZW. Today such influx of warm water off an ice shwlf has been shown to accelerate ice retreat (Holland et al., 2008; Mouginot et al., 2015). While it is likely that the WGC played an important role in sustaining ice retreat after the Younger Dryas and through the early Holocene (Andresen et al., 2011; Gramling, 2015), the lack of initial deglacial sediments does not allow us to determine whether the WGC also played a role in initiating the early ice retreat. After the Younger Dryas, the ice stream retreated rapidly into the fjords (Lane et al., 2014; Roberts et al., 2013).

Close inspection of TOPAS profiles from the outer shelf shows that thicker till deposits, or lobes, occur at three locations between the outer shelf moraine and the mid-shelf GZW (Fig. 2B). Each of these deposits occurs as an acoustically-homogenous lobe, interpreted in this environment as subglacial till following Dowdeswell et al. (2014), on the seaward side of a subtle bathymetric shallowing $20-60 \mathrm{~m}$ in height. These deposits may have accumulated as ice-marginal features during pauses in the ice retreat, indicating that retreat was episodic in nature (Andreassen et al., 2014; Dowdeswell et al., 2008, 2013; Dowdeswell and Fugelli, 2012; Evans et al., 2009; Ó Cofaigh, 2012; Ó Cofaigh et al., 2008). Slower retreat would be supported by the overall landward shallowing bathymetry on the outer shelf, with steps in the bathymetry temporarily stabilising the ice margin. Following this, the presence of the large GZW on the mid-shelf (Fig. 2A) confirms that the ice stabilised at that position for some time before a final retreat into the fjords.

Cosmogenic radiogenic nuclide (CRN) dates from $233 \mathrm{~m}$ above sea level on Ubekendt Ejland, which bisects the entrances to Karrats and Uummannaq fjords, indicate that this island became ice free by 12.4 kyr BP (Figure 1B; Roberts et al., 2013). Due to our interpretation of 
the ice retreat from the mid-shelf GZW, we believe that the CRN dates from Ubekendt Ejland are too old on account of either incomplete resetting of the cosmogenic isotope clock by glacial erosion, or ice thinning but not marginal retreat. In other aspects, our reconstruction is in agreement with terrestrial CRN ages and a radiocarbon date from Karrat Lake in the northern sector of the Uummannaq fjords (Lane et al., 2014). These dates indicate that the ice stream had retreated to the inner fjords by 11.6 BP (Fig. 1B) under the influence of rising sea level and deepening bathymetry (Lane et al., 2014). A parallel scenario is presented by Roberts et al. (2013) from the southern sector of the Uummannaq fjords, with rapid ice retreat into the fjords by 11.4 to $10.8 \mathrm{cal}$ kyr BP (Fig. 1B). We suggest that this rapid retreat represents the end phase of retreat off the mid-shelf GZW and that this event is captured on the outer shelf by the final phase of IRD.

The timing of the retreat of the Uummannaq Ice Stream from the outer shelf corresponds with the onset of the warmer Bølling-Allerød interstadial (Grootes et al., 1993), while the presence of the GZW and its inferred date on the mid-shelf corresponds with the Younger Dryas chron (Fig. 11a, b). This suggests that the Uummannaq Ice Stream was responsive to the climatic signals of the Bølling-Allerød and Younger Dryas, similar to findings from southern and northern Greenland (Knutz et al., 2011; Larsen et al., 2015). When compared with the GISP2 $\delta^{18} 0$ climate record (Grootes et al., 1993), stabilisation of the ice stream margin on the midshelf coincides with cooling from the Bølling interstadial into the Allerød period (Fig. 11b). The timing of the mid-shelf still-stand suggests that climatic cooling played a significant role in stabilising the ice stream. The uppermost IRD-rich interval in VC45 and VC43 commenced ca. 11.5 cal kyr BP, which we propose was coincident with the retreat from the GZW and deglaciation of MSM343520 and VC42 (Fig. 11a). Many of the terrestrial exposure dates on 
central West Greenland suggest that the ice margin did not retreat in earnest until the Younger Dryas ended and Holocene warming began in the Baffin Bay region (de Vernal and Hillaire-Marcel, 2006; Roberts et al., 2009, 2013). The warming effect was especially pronounced where the WGC had a strong impact on the eastern margin of Baffin Bay (Kaplan and Wolfe, 2006; Knutz et al., 2011; Roberts et al., 2009). After the Younger Dryas, the ice retreated rapidly across the Uummannaq Trough (Fig. 11a), and faunal evidence from VC42 suggests that retreat likely was aided by the presence of the WGC.

Evidence for a moraine-building Younger Dryas episode around Greenland has been scarce (Funder et al., 2011; Hall et al., 2008; Larsen et al., 2015; Miller, 2008). However, offshore evidence for the Younger Dryas ice margin is emerging off central West Greenland. Marine geological studies show that the LGM retreat of the ancestral Jakobshavns Isbrae from the outer shelf into Disko Bugt was succeeded by a Younger Dryas readvance to the shelf edge (ó Cofaigh et al., 2013b), while Younger Dryas-aged moraines suggest a readvance in northern Greenland (Larsen et al., 2015). The onset of rapid ice retreat from the outer Disko Trough via calving is constrained to $12.2 \pm 0.4$ cal kyr BP (Jennings et al., 2014). Rapid ice retreat onto land at the head of Disko Bugt was achieved by c. $10.1 \pm 0.3$ cal kyr BP (Kelley et al., 2013), and followed by subsequent stillstands and moraine formation episodes (Hogan et al., 2011; Kelley et al., 2013; Young et al., 2011). The results of this study on the Uummannaq Trough, in combination with the Disko Trough studies, indicate a positive mass balance response to Younger Dryas cooling by central West Greenland ice streams.

\section{Conclusions}


The Greenland ice sheet margin was in retreat from its offshore Last Glacial Maximum (LGM) position on the outer shelf of the Uummannaq Trough, West Greenland, by 15.0 cal kyr BP, around the start of the Bølling period. By this time, the 'warm' West Greenland Current (WGC) was affecting the outer shelf, as evidenced by the presence of Atlantic Water foraminifera in the earliest marine sediments overlaying the glacial diamicton. This is the earliest record of Atlantic Water found on the West Greenland shelf after the LGM. Unfortunately, the palaeoenvironments represented in the outermost shelf core at this site suggest that the sedimentary record did not include the most ice-proximal conditions (cf. Ó Cofaigh et al., 2013a), and the data thus does not allow tracking of the initial retreat of the LGM ice or the first onset of the WGC.

Geophysical data indicate that the retreating ice stream stabilised on the mid-shelf sometime after 13.9 cal kyr BP, and likely remained there until the end of the Younger Dryas event, forming a large grounding-zone wedge (GZW) (Dowdeswell et al., 2014). The foraminiferal fauna during this time indicate strong stratification with a Polar or meltwater lid, which was likely sourced from meltwater flux from the local ice margin on the mid-shelf.

Based on a concurrent IRD signal in the two outer shelf core the Uummannaq ice stream began to retreat from the GZW by 11.5 cal kyr BP. Intervals of high IRD concentration on the outer and middle shelf suggest that the retreat from the GZW involved calving at an icestream margin, exporting icebergs across Uummannaq Trough.

The ice stream had retreated landward of the mid-shelf by 10.8 cal kyr BP, but the long sequence of distal glacimarine sediments preceding the tie-point for the date suggests that VC42 was deglaciated well before this time. Lithofacies in VC42 indicate strong meltwater and IRD production during ice retreat into rapidly deepening water depths. We propose that the 
retreat from the mid-shelf GZW by 11.5 cal kyr BP was concurrent with the deglaciation of VC42 on the mid-shelf, as a result of very rapid ice retreat at the end of the Younger Dryas cold event, which could have been aided by the warm WGC. 


\section{Acknowledgements}

We are grateful to the captain and crew of the RRS James Clark Ross and to the science party of cruise JR175 (2009), without whom this work could not be carried out. Thanks also to Patrick Cappa for assistance in preparing the radiocarbon samples for dating. Thanks to Anders Anker Bjørk, from the University of Copenhagen, for making the base map for Figure 1.

\section{Funding}

Participation in this study was supported by Unites States National Science Foundation awards: NSF OPP-0713755 and NSF P2C2-1203492 to the University of Colorado. The data were collected during cruise JR175 of the RRS James Clark Ross to West Greenland in 2009 and was funded by the UK Natural Environment Research Council (grant NE/D001951/1). This study was funded by the Danish Council for Independent Research, Natural Science (project no. 12-126709/FNU). The research leading to these results has also received funding from the European Union's Seventh Framework programme (FP7/2007-2013) under grant agreement no 243908, 'Past4Future, Climate change-Learning from the past climate' as well as from Aarhus University, Denmark. 


\section{References}

Alley RB, Andrews JT, Brigham-Grette J, Clarke GKC, Cuffey KM, Fitzpatrick JJ, et al. (2010) History of the Greenland Ice Sheet: paleoclimatic insights. Quaternary Science Reviews 29(1516): 1728-1756: doi:10.1016/j.quascirev.2010.02.007.

Andreassen K, Winsborrow MCM, Bjarnadóttir LR and Rüther DC (2014) Ice stream retreat dynamics inferred from an assemblage of landforms in the northern Barents Sea. Quaternary Science Reviews 92: 246-257: doi:10.1016/j.quascirev.2013.09.015.

Andresen CS, McCarthy DJ, Dylmer CV, Seidenkrantz M-S, Kuijpers A and Lloyd JM (2011) Interaction between subsurface ocean waters and calving of the Jakobshavn Isbræ during the late Holocene. The Holocene 21(2): 211-224: doi:10.1177/0959683610378877.

Andrews JT, Bjork AA, Eberl DD, Jennings AE and Verplanck EP (2015) Significant differences in late Quaternary bedrock erosion and transport: East versus West Greenland $\sim 70^{\circ} \mathrm{N}$ evidence from the mineralogy of offshore glacial marine sediments. Journal of Quaternary Science 30(5): 452-463: doi:10.1002/jqs.2787.

Andrews JT and Eberl DD (2011) Surface (sea floor) and near-surface (box cores) sediment mineralogy in Baffin Bay as a key to sediment provenance and ice sheet variations. Canadian Journal of Earth Sciences 48(9): 1307-1328: doi:10.1139/e11-021.

Andrews JT, Kirby ME, Aksu A, Barber DC and Meese D (1998) Late Quaternary Detrital Carbonate (DC-) Layers in Baffin Bay Marine Sediments $\left(67^{\circ}-74^{\circ} \mathrm{N}\right)$ : Correlation with Heinrich Events in the North Atlantic? Quaternary Science Reviews 17(12): 1125-1137: doi:10.1016/S0277-3791(97)00064-4.

Andrews JT and Vogt C (2014) Source to sink: Statistical identification of regional variations in the mineralogy of surface sediments in the western Nordic Seas $\left(58^{\circ} \mathrm{N}-75^{\circ} \mathrm{N} ; 10^{\circ} \mathrm{W}-40^{\circ} \mathrm{W}\right)$. Marine Geology 357: 151-162: doi:10.1016/j.margeo.2014.08.005.

Bakke J, Lie Ø, Heegaard E, Dokken T, Haug GH, Birks HH, et al. (2009) Rapid oceanic and atmospheric changes during the Younger Dryas cold period. Nature Geoscience 2: 202-205: doi:10.1038/ngeo439.

Batchelor CL and Dowdeswell JA (2014) The physiography of High Arctic cross-shelf troughs. Quaternary Science Reviews 92: 68-96: doi:10.1016/j.quascirev.2013.05.025.

Batchelor CL and Dowdeswell JA (2015) Ice-sheet grounding-zone wedges (GZWs) on highlatitude continental margins. Marine Geology 363: 65-92: doi:10.1016/j.margeo.2015.02.001.

Bindschadler R (2006) Climate Change: Hitting the Ice Sheets Where It Hurts. Science 311(5768): 1720-1721: doi:10.1126/science.1125226. 
Clark CD, Tulaczyk SM, Stokes CR and Canals M (2003) A groove-ploughing theory for the production of mega-scale glacial lineations, and implications for ice-stream mechanics. Journal of Glaciology 49(165): 240-256: doi:10.3189/172756503781830719.

Cowan EA, Cai J, Powell RD, Clark JD and Pitcher JN (1997) Temperate glacimarine varves: An example from Disenchantment Bay, southern Alaska. Journal of Sedimentary Research 67(3): 536-549.

de Vernal A and Hillaire-Marcel C (2006) Provincialism in trends and high frequency changes in the northwest North Atlantic during the Holocene. Global and Planetary Change 54(3-4): 263-290: doi:10.1016/j.gloplacha.2006.06.023.

Dowdeswell JA, Cofaigh CÓ and Pudsey CJ (2004) Thickness and extent of the subglacial till layer beneath an Antarctic paleo-ice stream. Geology 32(1): 13: doi:10.1130/G19864.1.

Dowdeswell JA, Evans J and Ó Cofaigh C (2010) Submarine landforms and shallow acoustic stratigraphy of a $400 \mathrm{~km}$-long fjord-shelf-slope transect, Kangerlussuaq margin, East Greenland. Quaternary Science Reviews 29(25-26): 3359-3369:

doi:10.1016/j.quascirev.2010.06.006.

Dowdeswell JA and Fugelli EMG (2012) The seismic architecture and geometry of groundingzone wedges formed at the marine margins of past ice sheets. Geological Society of America Bulletin 124(11-12): 1750-1761: doi:10.1130/B30628.1.

Dowdeswell JA, Hogan KA, Arnold NS, Mugford RI, Wells M, Hirst JPP, et al. (2015) Sedimentrich meltwater plumes and ice-proximal fans at the margins of modern and ancient tidewater glaciers: Observations and modelling. Sedimentology: doi:10.1111/sed.12198.

Dowdeswell JA, Hogan KA, Ó Cofaigh C, Fugelli EMG, Evans J and Noormets R (2013) Late Quaternary ice flow in a West Greenland fjord and cross-shelf trough system: submarine landforms from Rink Isbrae to Uummannaq shelf and slope. Quaternary Science Reviews: doi:10.1016/j.quascirev.2013.09.007.

Dowdeswell JA, Hogan KA, Ó Cofaigh C, Fugelli EMG, Evans J and Noormets R (2014) Late Quaternary ice flow in a West Greenland fjord and cross-shelf trough system: submarine landforms from Rink Isbrae to Uummannaq shelf and slope. Quaternary Science Reviews 92: 292-309: doi:10.1016/j.quascirev.2013.09.007.

Dowdeswell JA, Ottesen D, Evans J, Cofaigh C ó and Anderson JB (2008) Submarine glacial landforms and rates of ice-stream collapse. Geology 36(10): 819: doi:10.1130/G24808A.1.

Dowdeswell, Whittington, Jennings, Andrews, Mackensen and Marienfeld (2000) An origin for laminated glacimarine sediments through sea-ice build-up and suppressed iceberg rafting: An origin for laminated glacimarine sediments. Sedimentology 47(3): 557-576:

doi:10.1046/j.1365-3091.2000.00306.x.

Dunlap E and Tang CCL (2006) Modelling the mean circulation of Baffin Bay. AtmosphereOcean 44(1): 99-109: doi:10.3137/ao.440107. 
Eberl DD (2003) User guide to RockJock -- A program for determining quantitative mineralogy from X-ray diffraction data. Washington, D.C.: United States Geological Survey, Open File Report 03-78.

Escher JC and Pulvertaft TCR (2010) Geological map of Greenland, 1:2500000. Copenhagen: Geological Survey of Greenland. Available at: http://www.geus.dk/program-areas/rawmaterials-greenl-map/greenland/gr-map/kost_1-uk.htm.

Evans J, Ó Cofaigh C, Dowdeswell JA and Wadhams P (2009) Marine geophysical evidence for former expansion and flow of the Greenland Ice Sheet across the north-east Greenland continental shelf. Journal of Quaternary Science 24(3): 14: doi:10.1002/jqs.1231.

Funder S, Kjeldsen KK, Kjaer K and OCofaigh C (2011) The Greenland Ice Sheet During the Past 300,000 Years: A Review. In: Ehlers J, Gibbard PL and Hughes PD (eds) Developments in Quaternary Sciences. Amsterdam, The Netherlands: Elsevier, 699-713.

Gilbert R, Nielsen N, Desloges JR and Rasch M (1998) Contrasting glacimarine sedimentary environments of two arctic fiords on Disko, West Greenland. Marine Geology 147(1-4): 63-83: doi:10.1016/S0025-3227(98)00008-5.

Gramling C (2015) How warming oceans unleashed an ice stream. Science 350(6262): 728728: doi:10.1126/science.350.6262.728.

Granath G (1984) Application of fuzzy clustering and fuzzy classification to evaluate the provenance of glacial till. Journal of the International Association for Mathematical Geology 16(3): 283-301: doi:10.1007/BF01032692.

Grobe H (1987) A Simple Method for the Determination of Ice-Rafted Debris in Sediment Cores. Polarforschung 57(3): 123.126.

Grootes PM, Stuiver M, White JWC, Johnsen S and Jouzel J (1993) Comparison of oxygen isotope records from the GISP2 and GRIP Greenland ice cores. Nature 366:

doi:10.1038/366552a0.

Hall B, Baroni C, Denton G, Kelly MA and Lowell T (2008) Relative sea-level change, Kjove Land, Scoresby Sund, East Greenland: Implications for seasonality in Younger Dryas time. Quaternary Science Reviews 27(25-26): 2283-2291: doi:10.1016/j.quascirev.2008.08.001.

Hogan KA, Dix JK, Lloyd JM, Long AJ and Cotterill CJ (2011) Seismic stratigraphy records the deglacial history of Jakobshavn Isbrae, West Greenland. Journal of Quaternary Science 26(7): 757-766: doi:10.1002/jqs.1500.

Hogan KA, Dowdeswell JA and Ó Cofaigh C (2012) Glacimarine sedimentary processes and depositional environments in an embayment fed by West Greenland ice streams. Marine Geology 311-314: 1-16: doi:10.1016/j.margeo.2012.04.006.

Holland DM, Thomas RH, de Young B, Ribergaard MH and Lyberth B (2008) Acceleration of Jakobshavn Isbræ triggered by warm subsurface ocean waters. Nature Geoscience 1(10): 659 - 664: doi:10.1038/ngeo316. 
Howat IM, Joughin I and Scambos TA (2007) Rapid Changes in Ice Discharge from Greenland Outlet Glaciers. Science 315(5818): 1559-1561: doi:10.1126/science.1138478.

Jennings AE (1993) The Quaternary History of Cumberland Sound, Southeastern Baffin Island: The Marine Evidence. Géographie physique et Quaternaire 47(1): 21: doi:10.7202/032929ar.

Jennings AE, Grönvold K, Hilberman R, Smith M and Hald M (2002) High-resolution study of Icelandic tephras in the Kangerlussuaq Trough, southeast Greenland, during the last deglaciation. Journal of Quaternary Science 17(8): 747-757: doi:10.1002/jqs.692.

Jennings AE, Hald M, Smith M and Andrews JT (2006) Freshwater forcing from the Greenland Ice Sheet during the Younger Dryas: Evidence from southeastern Greenland shelf cores. Quaternary Science Reviews 25(3-4): 282-298: doi:10.1016/j.quascirev.2005.04.006.

Jennings AE and Helgadottir G (1994) Foraminiferal assemblages from the fjords and shelf of eastern Greenland. The Journal of Foraminiferal Research 24(2): 123-144:

doi:10.2113/gsjfr.24.2.123.

Jennings AE, Kelly J, Shreve B, Reed M and Andrews JT (2013) Ice Rafting Events off Central West Greenland: A Record of Ice Sheet Retreat from Northern Baffin Bay? paper presented at the GSA. Talk. Geological Society of America.

Jennings AE, Walton ME, Ó Cofaigh C, Kilfeather A, Andrews JT, Ortiz JD, et al. (2014) Paleoenvironments during Younger Dryas-Early Holocene retreat of the Greenland Ice Sheet from outer Disko Trough, central west Greenland. Journal of Quaternary Science 29(1): 27-40: doi:10.1002/jqs.2652.

Jennings AE and Weiner NJ (1996) Environmental change in eastern Greenland during the last 1300 years: evidence from foraminifera and lithofacies in Nansen Fjord, $68 \mathrm{~N}$. The Holocene 6(2): 179-161: doi:10.1177/095968369600600205.

Joughin I, Alley RB and Holland DM (2012) Ice-Sheet Response to Oceanic Forcing. Science 338(6111): 1172-1176: doi:10.1126/science.1226481.

Kaplan MR and Wolfe AP (2006) Spatial and temporal variability of Holocene temperature in the North Atlantic region. Quaternary Research 65(2): 223-231:

doi:10.1016/j.yqres.2005.08.020.

Kelley SE, Briner JP and Young NE (2013) Rapid ice retreat in Disko Bugt supported by 10Be dating of the last recession of the western Greenland Ice Sheet. Quaternary Science Reviews 82: 13-22: doi:10.1016/j.quascirev.2013.09.018.

Knudsen KL, Stabell B, Seidenkrantz M-S, EirÍksson J and Blake W (2008) Deglacial and Holocene conditions in northernmost Baffin Bay: sediments, foraminifera, diatoms and stable isotopes. Boreas 37(3): 346-376: doi:10.1111/j.1502-3885.2008.00035.x.

Knutz PC, Sicre M-A, Ebbesen H, Christiansen S and Kuijpers A (2011) Multiple-stage deglacial retreat of the southern Greenland Ice Sheet linked with Irminger Current warm water transport. Paleoceanography 26(3): PA3204: doi:10.1029/2010PA002053. 
Kovach (1998) Multi-Variate Statistical Package. Pentraeth, Wales: Kovach Computing Services.

Lane TP, Roberts DH, Rea BR, Ó Cofaigh C, Vieli A and Rodés A (2014) Controls upon the Last Glacial Maximum deglaciation of the northern Uummannaq Ice Stream System, West Greenland. Quaternary Science Reviews 92: 324-344: doi:10.1016/j.quascirev.2013.09.013.

Larsen NK, Funder S, Linge H, Möller P, Schomacker A, Fabel D, et al. (2015) A Younger Dryas re-advance of local glaciers in north Greenland. Quaternary Science Reviews. Available at: http://linkinghub.elsevier.com/retrieve/pii/S0277379115301578: doi:10.1016/j.quascirev.2015.10.036.

Lloyd JM (2006a) Late Holocene environmental change in Disko Bugt, west Greenland: interaction between climate, ocean circulation and Jakobshavn Isbrae. Boreas 35(1): 35-49: doi:10.1111/j.1502-3885.2006.tb01111.x.

Lloyd JM (2006b) Modern distribution of benthic foraminifera from Disko Bugt, west Greenland. The Journal of Foraminiferal Research 36(4): 315.

Lloyd JM, Moros M, Perner K, Telford RJ, Kuijpers A, Jansen E, et al. (2011) A 100 yr record of ocean temperature control on the stability of Jakobshavn Isbrae, West Greenland. Geology 39(9): 867-870: doi:10.1130/G32076.1.

Lloyd JM, Park LA, Kuijpers A and Moros M (2005) Early Holocene palaeoceanography and deglacial chronology of Disko Bugt, West Greenland. Quaternary Science Reviews 24(14): 1741-1755: doi:10.1016/j.quascirev.2004.07.024.

Long AJ (2009) Back to the future: Greenland's contribution to sea-level change. GSA Today 19(6): 4: doi:10.1130/GSATG40A.1.

McCarthy D (2011) Late Quaternary ice-ocean interactions in central West Greenland. Ph.D. Thesis, Scotland, UK, Durham University.

Miller GH (2008) Greenland's elusive younger dryas. Quaternary Science Reviews 27(25-26): 2271-2272: doi:10.1016/j.quascirev.2008.10.001.

Misnasny B and McBratney AB (2002) FuzMe. University of Sydney, Australia: Australian Center for Precision Agriculture.

Mouginot J, Rignot E, Scheuchl B, Fenty I, Khazendar A, Morlighem M, et al. (2015) Fast retreat of Zachariae Isstrom, northeast Greenland. Science 350(6266): 1357-1361:

doi:10.1126/science.aac7111.

Mowatt TC and Naidu AS (1994) Summary Review of the Geology of Greenland as Related to Geological and Engineering Aspects of Sampling Beneath the Inland Ice. BLM-Alaska Open File Report. Alaska: U.S. Department of the Interior, Bureau of Land Management, 59. 
Mugford RI and Dowdeswell JA (2011) Modeling glacial meltwater plume dynamics and sedimentation in high-latitude fjords. Journal of Geophysical Research: Earth Surface 116(F1): F01023: doi:10.1029/2010JF001735.

Münchow A, Falkner KK and Melling H (2015) Baffin Island and West Greenland Current Systems in northern Baffin Bay. Progress in Oceanography 132: 305-317: doi:10.1016/j.pocean.2014.04.001.

Murton J, Bateman M, Dallimore S, Teller J and Yang Z (2010) Identification of Younger Dryas outburst flood path from Lake Agassiz to the Arctic Ocean. Nature 464(7289): 740-743: doi:10.1038/nature08954.

Nick FM, Vieli A, Andersen ML, Joughin I, Payne A, Edwards TL, et al. (2013) Future sea-level rise from Greenland's main outlet glaciers in a warming climate. Nature 497(7448): 235-238: doi:10.1038/nature12068.

Nick FM, Vieli A, Howat IM and Joughin I (2009) Large-scale changes in Greenland outlet glacier dynamics triggered at the terminus. Nature Geoscience 2(2): 110-114: doi:10.1038/ngeo394.

Ó Cofaigh C (2012) Ice sheets viewed from the ocean: the contribution of marine science to understanding modern and past ice sheets. Philosophical transactions. Series A, Mathematical, physical, and engineering sciences 370(1980): 5512-5539: doi:10.1098/rsta.2012.0398.

Ó Cofaigh C, Andrews JT, Jennings AE, Dowdeswell JA, Hogan KA, Kilfeather AA, et al. (2013a) Glacimarine lithofacies, provenance and depositional processes on a West Greenland troughmouth fan. Journal of Quaternary Science 28: doi:10.1002/jqs.2569.

Ó Cofaigh C and Dowdeswell JA (2001) Laminated sediments in glacimarine environments: diagnostic criteria for their interpretation. Quaternary Science Reviews 20(13): 1411-1436: doi:10.1016/S0277-3791(00)00177-3.

Ó Cofaigh C, Dowdeswell JA, Allen CS, Hiemstra JF, Pudsey CJ, Evans J, et al. (2005) Flow dynamics and till genesis associated with a marine-based Antarctic palaeo-ice stream. Quaternary Science Reviews 24(5-6): 709-740: doi:10.1016/j.quascirev.2004.10.006.

Ó Cofaigh C, Dowdeswell JA, Evans J and Larter RD (2008) Geological constraints on Antarctic palaeo-ice-stream retreat. Earth Surface Processes and Landforms 33(4): 513-525:

doi:10.1002/esp.1669.

Ó Cofaigh C, Dowdeswell JA, Jennings AE, Hogan KA, Kilfeather A, Hiemstra JF, et al. (2013b) An extensive and dynamic ice sheet on the West Greenland shelf during the last glacial cycle. Geology 41(2): 219-222: doi:10.1130/G33759.1.

Ó Cofaigh C, Evans J, Dowdeswell JA and Larter RD (2007) Till characteristics, genesis and transport beneath Antarctic paleo-ice streams. Journal of Geophysical Research 112: F03006: doi:10.1029/2006JF000606. 
Parnell J, Bowden S, Andrews JT and Taylor C (2007) Biomarker determination as a provenance tool for detrital carbonate events (Heinrich events?): Fingerprinting Quaternary glacial sources into Baffin Bay. Earth and Planetary Science Letters 257(1-2): 71-82: doi:10.1016/j.epsl.2007.02.021.

Pearce C, Seidenkrantz M-S, Kuijpers A and Reynisson NF (2014) A multi-proxy reconstruction of oceanographic conditions around the Younger Dryas-Holocene transition in Placentia Bay, Newfoundland. Marine Micropaleontology 112: 39-49: doi:10.1016/j.marmicro.2014.08.004.

Pedersen GK and Pulvertaft TCR (1992) The nonmarine Cretaceous of the West Greenland Basin, onshore West Greenland. Cretaceous Research 13(3): 263-272: doi:10.1016/01956671(92)90002-8.

Powell RD (1990) Glacimarine processes at grounding-line fans and their growth to icecontact deltas. Geological Society, London, Special Publications 53(1): 53-73: doi:10.1144/GSL.SP.1990.053.01.03.

Principato SM, Jennings AE, Kristjansdottir GB and Andrews JT (2005) Glacial-marine or subglacial origin of diamicton units from the Southwest and North Iceland shelf: Implications for the glacial history of Iceland. Journal of Sedimentary Research 75(6): 968-983: doi:10.2110/jsr.2005.073.

Reimer P, Bard E, Bayliss A, Beck JW, Blackwell PG, Ramsey CB, et al. (2013) IntCal13 and Marine13 Radiocarbon Age Calibration Curves 0-50,000 Years cal BP. Radiocarbon 55(4): 1869-1887: doi:10.2458/azu_js_rc.55.16947.

Rignot E (2002) Mass Balance of Polar Ice Sheets. Science 297(5586): 1502-1506: doi:10.1126/science.1073888.

Rignot E and Kanagaratnam P (2006) Changes in the velocity structure of the Greenland Ice Sheet. Science 311(5763): 986-990: doi:10.1126/science.1121381.

Rignot E, Koppes M and Velicogna I (2010) Rapid submarine melting of the calving faces of West Greenland glaciers. Nature Geoscience 3: 187 - 191: doi:10.1038/ngeo765.

Rignot E, Velicogna I, van den Broeke MR, Monaghan A and Lenaerts JTM (2011) Acceleration of the contribution of the Greenland and Antarctic ice sheets to sea level rise. Geophysical Research Letters 38(5): L05503: doi:10.1029/2011GL046583.

Roberts DH, Long AJ, Schnabel C, Davies BJ, Xu S, Simpson MJR, et al. (2009) Ice sheet extent and early deglacial history of the southwestern sector of the Greenland Ice Sheet. Quaternary Science Reviews 28(25-26): 2760-2773: doi:10.1016/j.quascirev.2009.07.002.

Roberts DH, Rea BR, Lane TP, Schnabel C and Rodés A (2013) New constraints on Greenland ice sheet dynamics during the last glacial cycle: Evidence from the Uummannaq ice stream system. Journal of Geophysical Research: Earth Surface 118(2): 519-541:

doi:10.1002/jgrf.20032. 
Scott DB and Vilks G (1991) Benthic foraminifera in the surface sediments of the deep-sea Arctic Ocean. The Journal of Foraminiferal Research 21(1): 20-38: doi:10.2113/gsjfr.21.1.20.

Seidenkrantz M-S, Ebbesen H, Aagaard-Sørensen S, Moros M, Lloyd JM, Olsen J, et al. (2013) Early Holocene large-scale meltwater discharge from Greenland documented by foraminifera and sediment parameters. Palaeogeography, Palaeoclimatology, Palaeoecology 391: 71-81: doi:10.1016/j.palaeo.2012.04.006.

Simon Q, St-Onge G and Hillaire-Marcel C (2012) Late Quaternary chronostratigraphic framework of deep Baffin Bay glaciomarine sediments from high-resolution paleomagnetic data. Geochemistry, Geophysics, Geosystems 13: Q0A003: doi:10.1029/2012GC004272.

Steenfelt A, Thomassen B, Lind M and Kyed J (1998) Karrat 97: reconnaissance mineral exploration in central West Greenland. Bulletin. GEUS: GEUS, 73-80.

Steinsund PI (1994) Benthic Foraminifera in Surface Sediments of the Barents and Kara Seas: Modern and Late Quaternary Applications. Doctor Scientiarum thesis, Institute of Biology and Geology, University of Tromsø.

Straneo F, Curry RG, Sutherland DA, Hamilton GS, Cenedese C, Våge K, et al. (2011) Impact of fjord dynamics and glacial runoff on the circulation near Helheim Glacier. Nature Geoscience 4(5): 322-327: doi:10.1038/ngeo1109.

Straneo F, Hamilton GS, Sutherland DA, Stearns LA, Davidson F, Hammill MO, et al. (2010) Rapid circulation of warm subtropical waters in a major glacial fjord in East Greenland. Nature Geoscience 3(3): 182-186: doi:10.1038/ngeo764.

Stuiver M, Reimer PJ and Reimer RW (2005) CALIB 5.0..

Syvitski JPM (1989) On the deposition of sediment within glacier-influenced fjords: Oceanographic controls. Marine Geology 85(2-4): 301-329: doi:10.1016/00253227(89)90158-8.

Tang C and Dunlap E (2007) Modeling annual variation of sea-ice cover in Baffin Bay. paper presented at the The Seventeenth International Offshore and Polar Engineering Conference. Lisbon, Portugal.

Tang C, Ross C, Yao T, Petrie B, Detracey B and Dunlap E (2004) The circulation, water masses and sea-ice of Baffin Bay. Progress In Oceanography 63(4): 183-228:

doi:10.1016/j.pocean.2004.09.005.

Ullrich AD, Cowan EA, Zellers SD, Jaeger JM and Powell RD (2009) Intra-annual Variability in Benthic Foraminiferal Abundance in Sediments of Disenchantment Bay, an Alaskan Glacial Fjord. Arctic, Antarctic, and Alpine Research 41(2): 257-271: doi:10.1657/1938-424641.2.257.

van den Broeke M, Bamber J, Ettema J, Rignot E, Schrama E, van de Berg WJ, et al. (2009) Partitioning Recent Greenland Mass Loss. Science 326(5955): 984-986:

doi:10.1126/science.1178176. 
Young NE, Briner JP, Stewart HAM, Axford Y, Csatho B, Rood DH, et al. (2011) Response of Jakobshavn Isbrae, Greenland, to Holocene climate change. Geology 39(2): 131-134: doi:10.1130/G31399.1. 


\section{Table Captions}

Table 1. Location and measurements of cores discussed in this study.

Table 2. Radiocarbon dates and their calibrations from marine sediment cores in the Uummannaq Trough. The ${ }^{14} \mathrm{C}$ ages were calibrated using the Marine13 dataset and a $\Delta \mathrm{R}$ of $140 \pm 30$.

Table 3. Foraminiferal species and their established environmental preferences. 


\section{Figure captions}

Figure 1. A) Location of the Uummannaq system, West Greenland; the main ocean currents are shown, after Jennings et al. (2013). Map created in Ocean Data Viewer, available at http://data.unep-wcmc.org. B) Map of the Uummannaq Trough, including bathymetry, location of core sites and deglacial dates. The ice margin deglaciation date of 11.4 BP was determined by Roberts et al. (2013) (orange diamond); the Karrat Lake deglaciation date (11.6 BP) was determined by Lane et al. (2014) (purple diamond). The cores presented in this paper are labelled with green dots, while the cores included for comparison are labelled with yellow dots. The grey lines on the outer shelf and mid-shelf represent the ice extent at the Last Glacial Maximum (LGM) and the possible Younger Dryas stillstand. The translucent pink outline represents the "pinch-out" of the ice-rafted detritus (IRD) belt mentioned in the paper. The red dots and dark grey line in the fjords represents the deglacial dates found by Roberts et al. (2013). TMF = trough mouth fan (Dowdeswell et al., 2014; Ó Cofaigh et al., 2013a). C) Map of basic bedrock geology discussed in this paper. The bedrock discussed in this paper is shown in colour; the mineralogy of the seafloor and fjords is not discussed in this paper, and is shown in grey. The extant Greenland Ice Sheet is shown in white. Adapted from Roberts et al., 2013.

Figure 2. A) TOPAS sub-bottom profiles for the coring transect along the Uummannaq Trough. Solid lines indicate location of profiles B and E; the dotted line for profile F indicates where the profile for VC42 would fit on profile A, since VC42 is was taken approximately $4 \mathrm{~km}$ north of the long profile in A; B) Detailed profile across site of core VC45, showing stratification of sediment in basin between moraine features; $\mathbf{C}$ ) Bathymetry of the outer shelf showing moraine features described in the text; D) Details of mega-scale glacial lineations (MSGLs) near VC43 on the outer shelf; E) Detailed profile of core VC43, which is located west of the GZW on the outer shelf; F) Detailed profile across core site VC42, east of the moraine and GZW. This profile, and VC42, is located ca. $4 \mathrm{~km}$ north of the profile shown in panel A.

Figure 3. Lithofacies examples of core sediments based on x-radiographs (core depth-scale in cm downcore). Examples of each lithofacies are shown. A) L1, massive, matrix-supported diamicton; B) transition from L1 to L2, massive pebbly mud; C) transition from L1 to L2; D) L3, crudely-stratified, bioturbated mud with dispersed IRD; E) L4, laminated mud with 
dispersed IRD; F) L5, stratified pebbly mud; G) transition from L2 to L6, bioturbated mud. The thick, buff-coloured detrital carbonate (DC) layer is shown in both x-radiograph and core photograph (H). The b represents examples of bioturbation found in the cores.

Figure 4. Results from fuzzy mean statistical analysis of qXRD mineralogy. A) PC-1 scores for the individual cores; B) PC-1 scores for the two mineral clusters ( $2 \mathrm{a}$ and $2 \mathrm{~b}$ ); $\mathbf{C}$ ) distribution of minerals within the two mineral clusters; D) distribution of minerals within the cores.

Figures 5, 6 and 7. Sediment data for core VC45, including >2mm IRD counts, shear strength measurements, fuzzy mean-derived cluster analysis results of the qXRD mineralogy, benthic foraminifera per millilitre of wet sediment, core lithology and detailed core log. The legend for the core logs in figures 5, 6 and 7 is presented here. Arrows represent correlated dates and tie-points between cores.

Figure 6. Sediment data for core VC43 (see Fig. 5 for more detail).

Figure 7. Sediment data for core VC42 (see Fig. 5 for more detail).

Figure 8. Foraminiferal assemblage data for core VC45. Faunal data is shown in percentage (calcareous and agglutinated foraminifera add to 100\%; hubs and linings are included in the calcareous assemblage). Total foraminiferal concentration represents the total number of individual foraminifera per millilitre $(\mathrm{ml})$ sediment in the sample, and the total calcareous and total agglutinated curves concentrations represent the total number of respective foraminifera per $\mathrm{ml}$ sediment in each sample. The $>2 \mathrm{~mm}$ IRD is shown in as individual counts based on radiograph images. Foraminiferal zones are shown as dashed lines and designated F45-1, F45-2, etc. Lithological zones are shown in solid lines and designated L1, L2, etc. The grey box represents the compressed unit discussed in the text. Arrows represent correlated dates and tie-points between cores.

Figure 9. Foraminiferal assemblage data for core VC43. The core contained insufficient number of foraminiferal specimens to constitute an assemblage, so cluster analysis could not be run and no faunal zones were created. See Fig. 8 for further detail.

Figure 10. Foraminiferal assemblage data for core VC42. Foraminiferal zones are shown as dashed lines and designated F42-1, F42-2, etc. See Fig. 8 for more detail. 
Figure 11. A) Representation of the proposed retreat of the Uummannaq ice stream. The solid line represents the proposed ice retreat. The short dotted line represents the proposed still-stand of the ice on the mid-shelf, which formed the grounding zone wedge (GZW); the diamond represents the date by which Roberts et al. (2013) found exposure dates on Illorsuit Island; the stars represent the radiocarbon dates from this paper. B) Comparison of the Uummannaq ice stream retreat with the $\delta^{18} 0$ record from the GISP2 ice core record (Grootes et al., 1993). The darker grey bar on the right represents the time by which the ice had retreated from VC45, and the lighter grey bar represents the retreat from the proposed stillstand at the GZW on the mid-shelf. During the early Holocene, the ice continued to retreat across the shelf and into the fjords. 


$\begin{array}{cccccc}\text { Core } & \text { Latitude } & \text { Longitude } & \text { Water depth, } m & \text { Core length, cm } & \begin{array}{c}\text { Coring } \\ \text { technique }\end{array} \\ \text { JR175-VC45 } & 70.56650^{\circ} & -60.307500^{\circ} & 648 & 141 & \text { Vibro core } \\ \text { JR175-VC43 } & 70.62283^{\circ} & -59.620833^{\circ} & 629 & 315 & \text { Vibro core } \\ \text { JR175-VC42 } & 70.88217^{\circ} & -56.092500^{\circ} & 554 & 550 & \text { Vibro core } \\ \text { MSM343520 }^{7} 70.81585^{\circ} & -56.848300^{\circ} & 546 & 989 & \text { Gravity core }\end{array}$




\begin{tabular}{|c|c|c|c|c|c|c|}
\hline Core & Lab Code & Depth, $\mathrm{cm}$ & Material & ${ }^{14}$ Cage & $\begin{array}{l}\text { Cal. age } \\
\text { range, } 2 \sigma\end{array}$ & Cal. age, BP \\
\hline VC45 & CURL-14050 & $93-95$ & I. norcrossi & $12555 \pm 30$ & $\begin{array}{c}13760- \\
14037\end{array}$ & 13895 \\
\hline VC45 & AA-89913 & $125-127$ & $\begin{array}{c}\text { Mixed } \\
\text { benthic } \\
\text { foram. }\end{array}$ & $13211 \pm 92$ & $\begin{array}{c}14517- \\
15366\end{array}$ & 15041 \\
\hline $\mathrm{C} 43$ & CURL-14054 & $71-72.5$ & Mollusc shell & $10535 \pm 25$ & $\begin{array}{c}11257- \\
11722\end{array}$ & 11467 \\
\hline
\end{tabular}


Species

Calcareous Species

Bolivinellina pseudopunctata

Cassidulina neoteretis

Cassidulina reniforme

Cassidulina reniforme

Elphidium excavatum f. clavata

Islandiella norcrossi

Melonis barleeanus

Nonionellina labradorica

Pullenia osloensis

Stainforthia concava

Stainforthia feylingi

Stetsonia horvathi

Agglutinated Species

Adercotryma glomerata

Cribrostomoides crassimargo

Cuneata arctica

Deuterammina grahami

Portatrochammina bipolaris

Reophax catella

Reophax fusiformis

Saccammina difflugiformis

Spiroplectammina biformis

Textularia earlandi

Textularia torquata

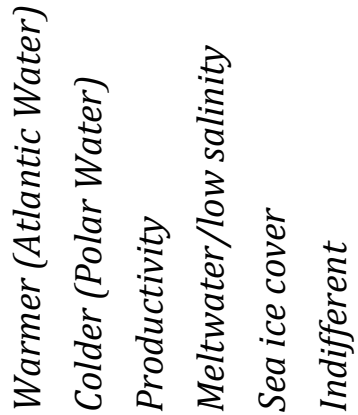

$\mathrm{X}$

(Jennings et al., 2004; Rytter et al., 2002)

(Jennings and Helgadottir, 1994; Jennings and Weiner, 1996; Seidenkrantz, 1995)

(Hald and Korsun, 1997; Mackensen et al., 1985)

(Korsun and Hald, 2000; Scott et al., 2008)

(Hald and Korsun, 1997; Jennings and

Helgadottir, 1994)

(Lloyd, 2006b; Steinsund, 1994)

(Caralp, 1989; Corliss, 1991; Jennings et al., 2004)

(Jennings et al., 2004; Polyak et al., 2002)

(Lloyd et al., 2011)

(Jennings and Helgadottir, 1994)

(Alve, 1994; Knudsen and Seidenkrantz,

X X 1994)

X (Lagoe, 1977)

$\mathrm{X}$

$x$

(Lloyd et al., 2011; Lloyd, 2006b)

(Lloyd, 2006b)

(Schafer and Cole, 1988)

$\mathrm{X}$ Indifferent

$\mathrm{X}$

(Jennings and Helgadottir, 1994; Lloyd, 2006b)

(Loeblich and Tappan, 1984)

(Hald and Korsun, 1997; Jennings and

Helgadottir, 1994)

(Schafer and Cole, 1988; Scott and Vilks, 1991)

(Jennings and Helgadottir, 1994; Schafer and Cole, 1986)

(Jennings and Helgadottir, 1994; Schafer and Cole, 1986)

X (Ishman and Foley, 1996) 


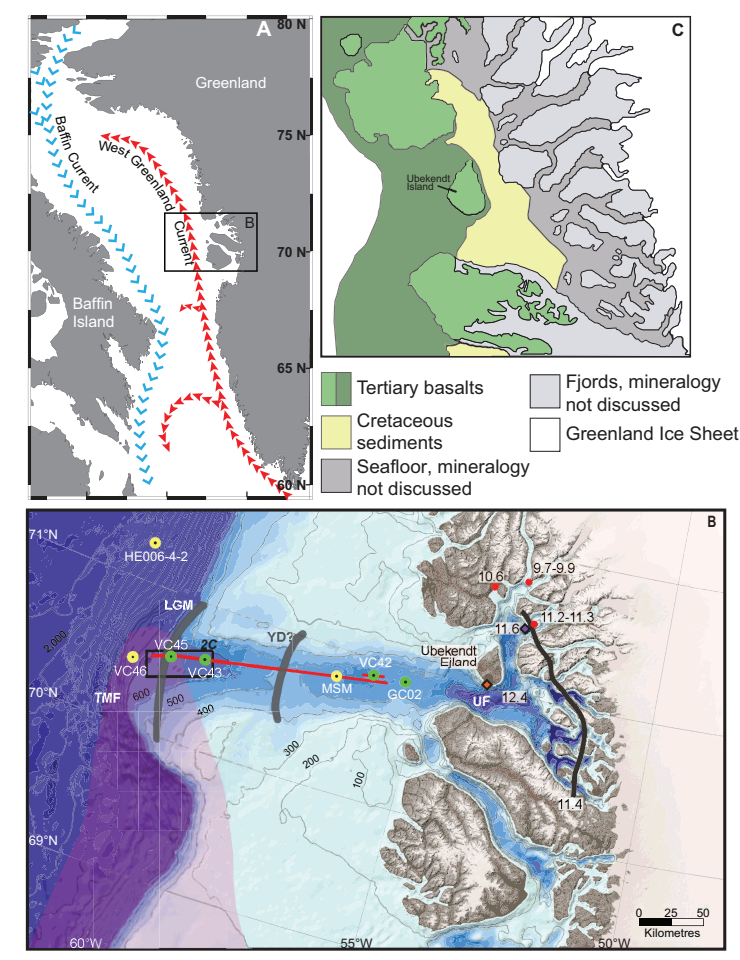

Figure 1 . 


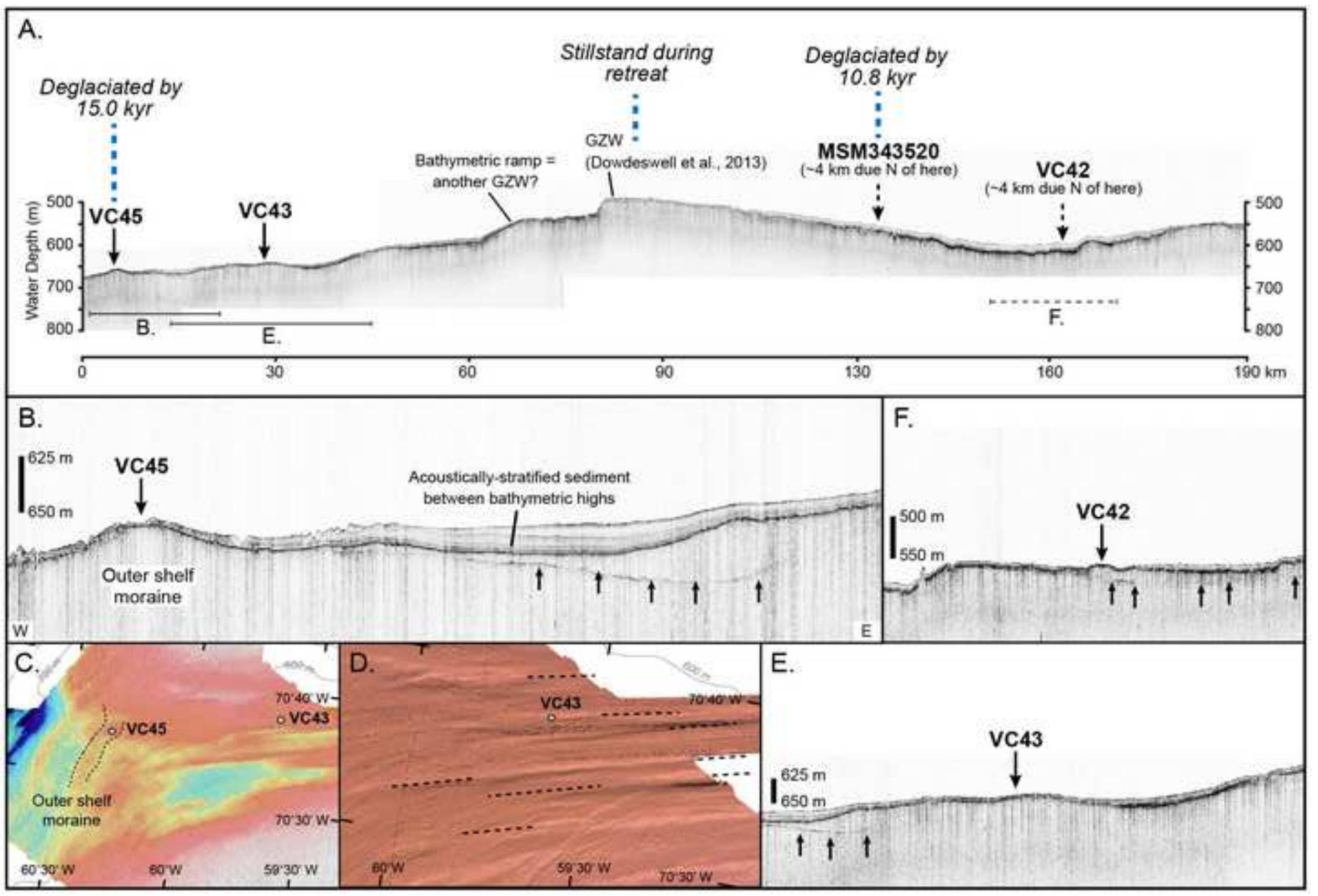


Figure 3
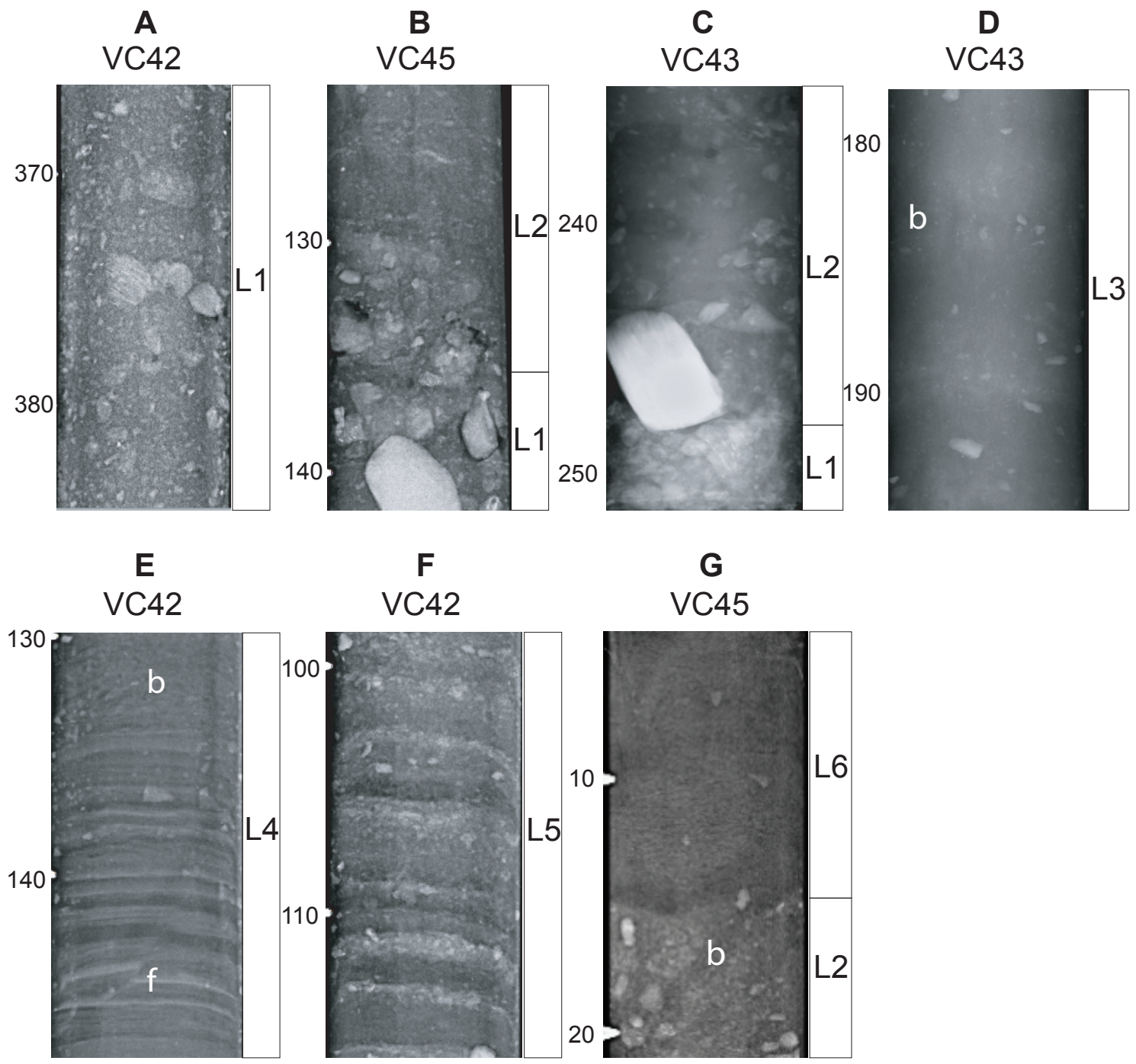

F

G

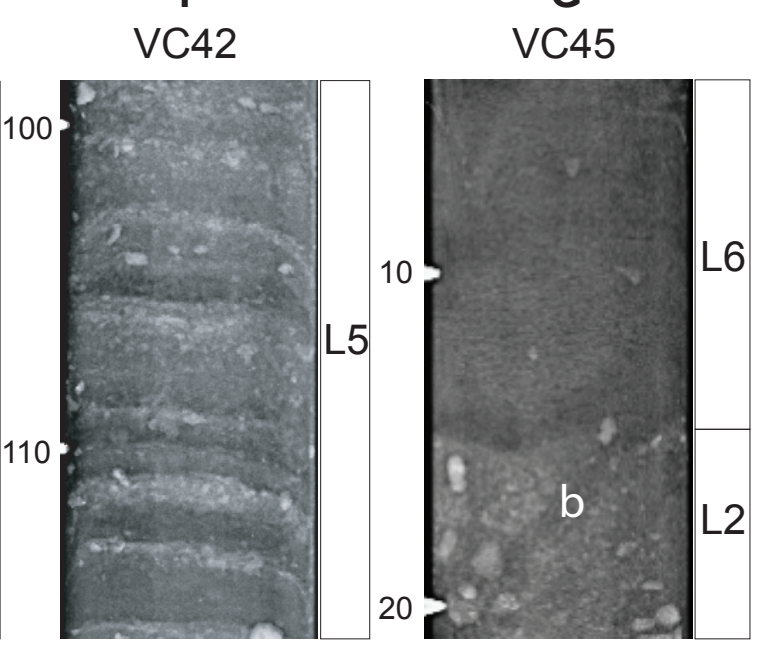

$\mathrm{H}$

DC Event

VC 45
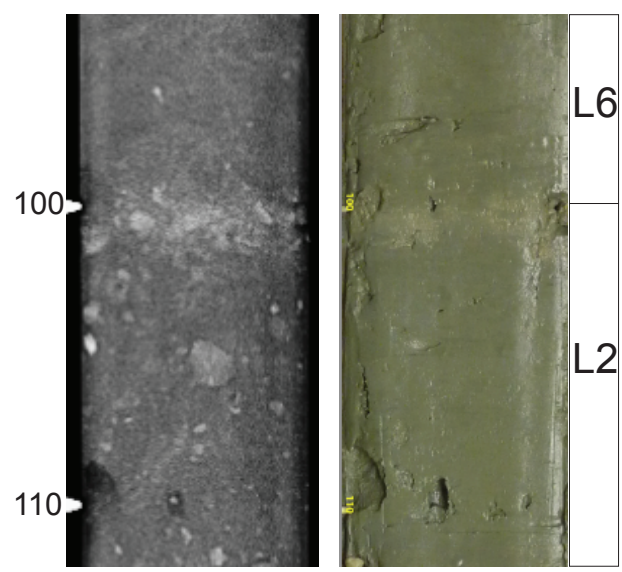
Figure 4
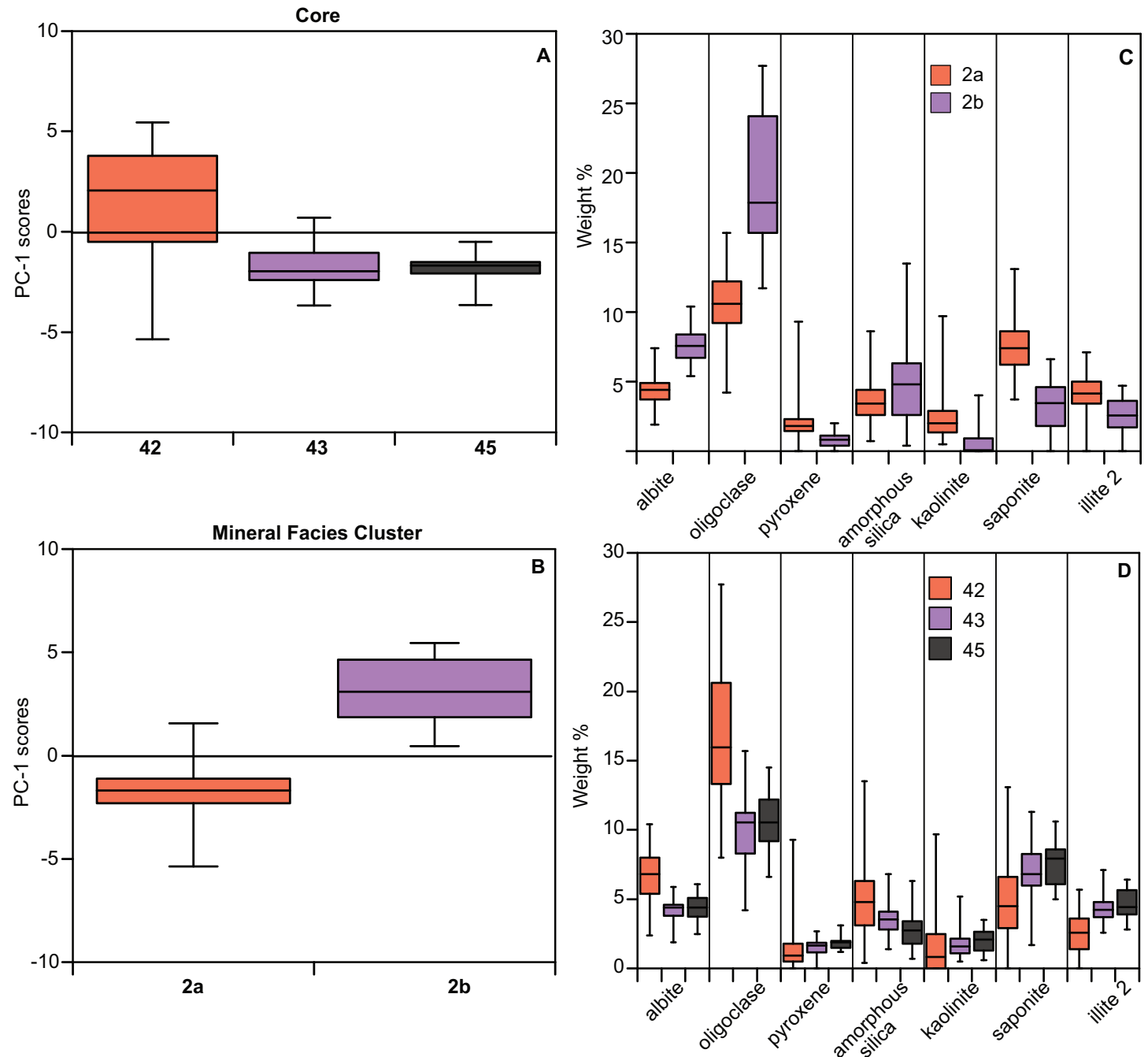


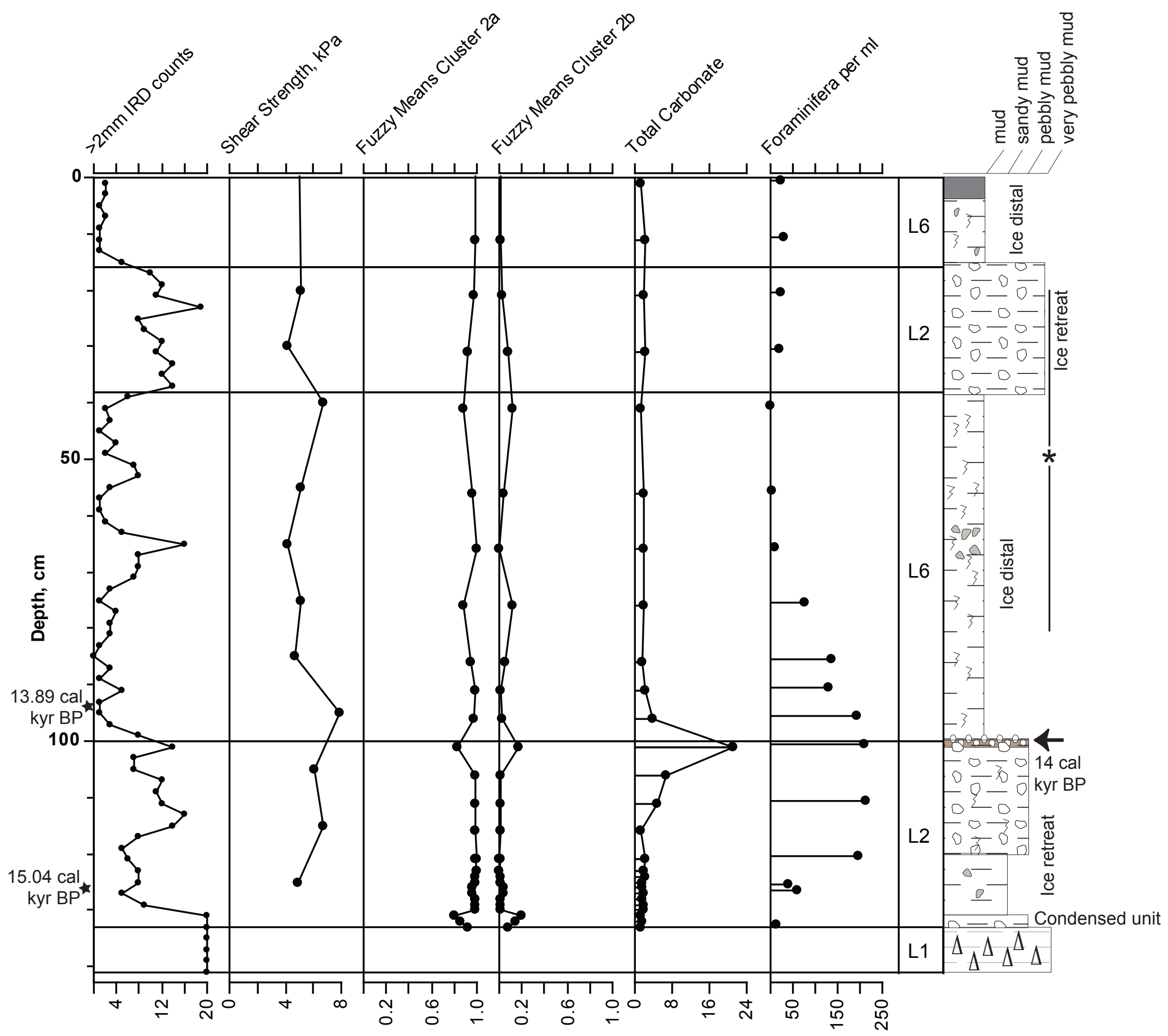

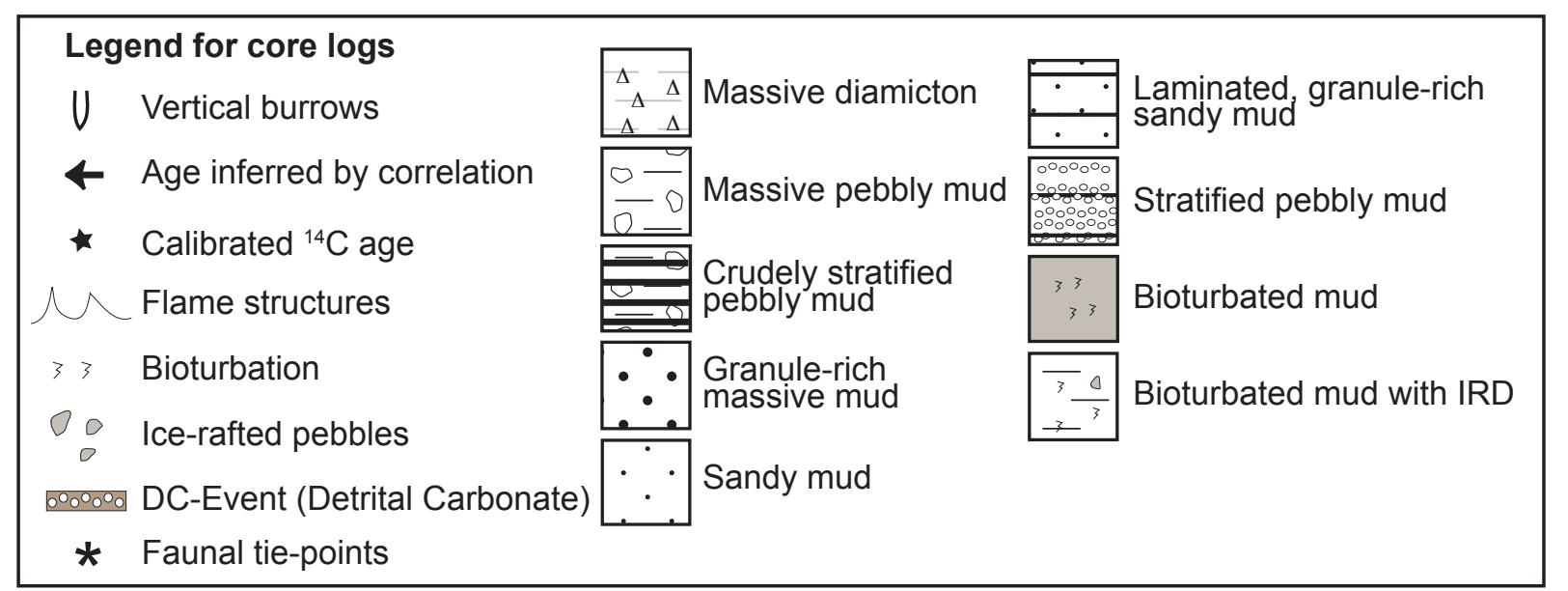




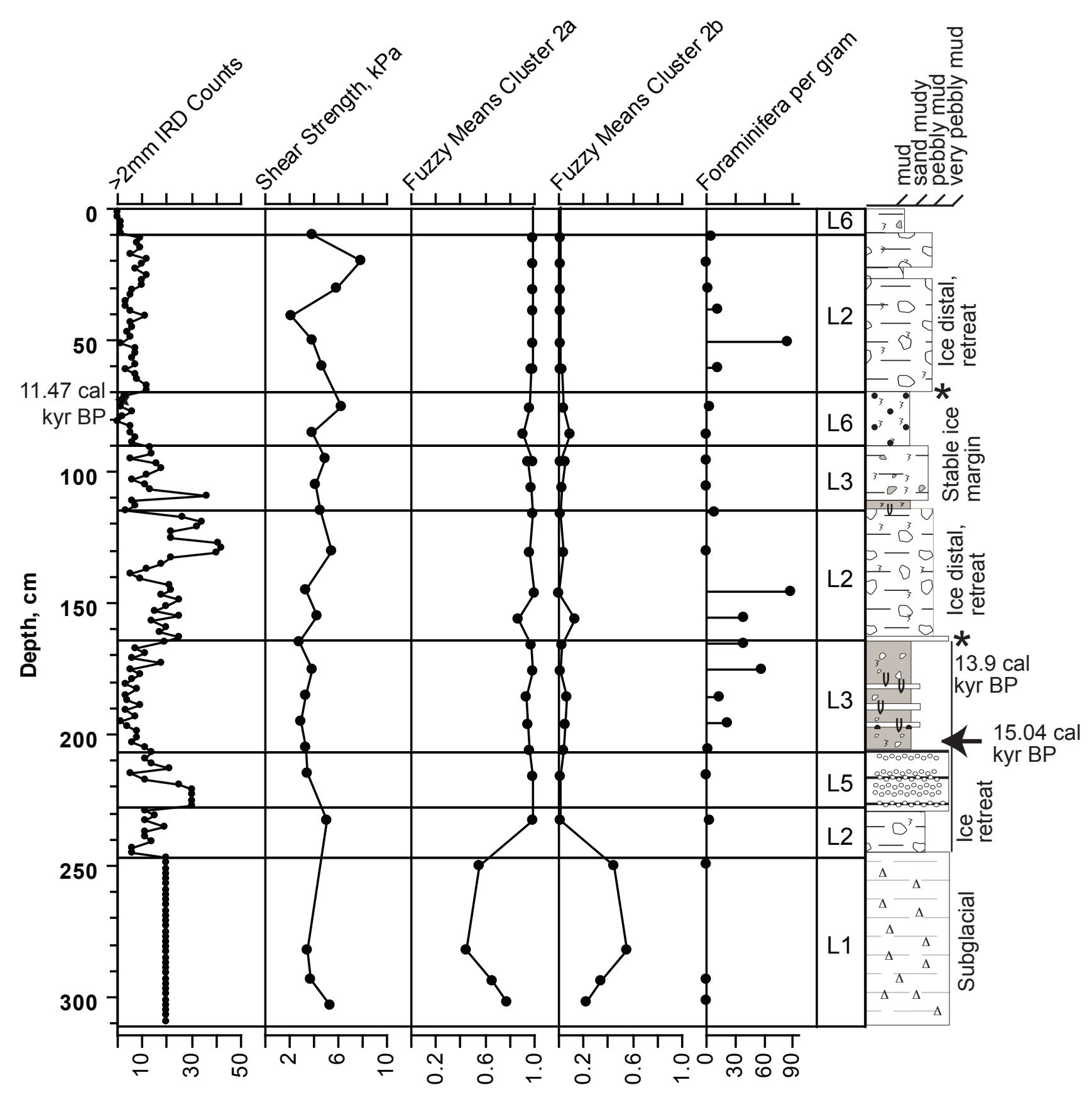




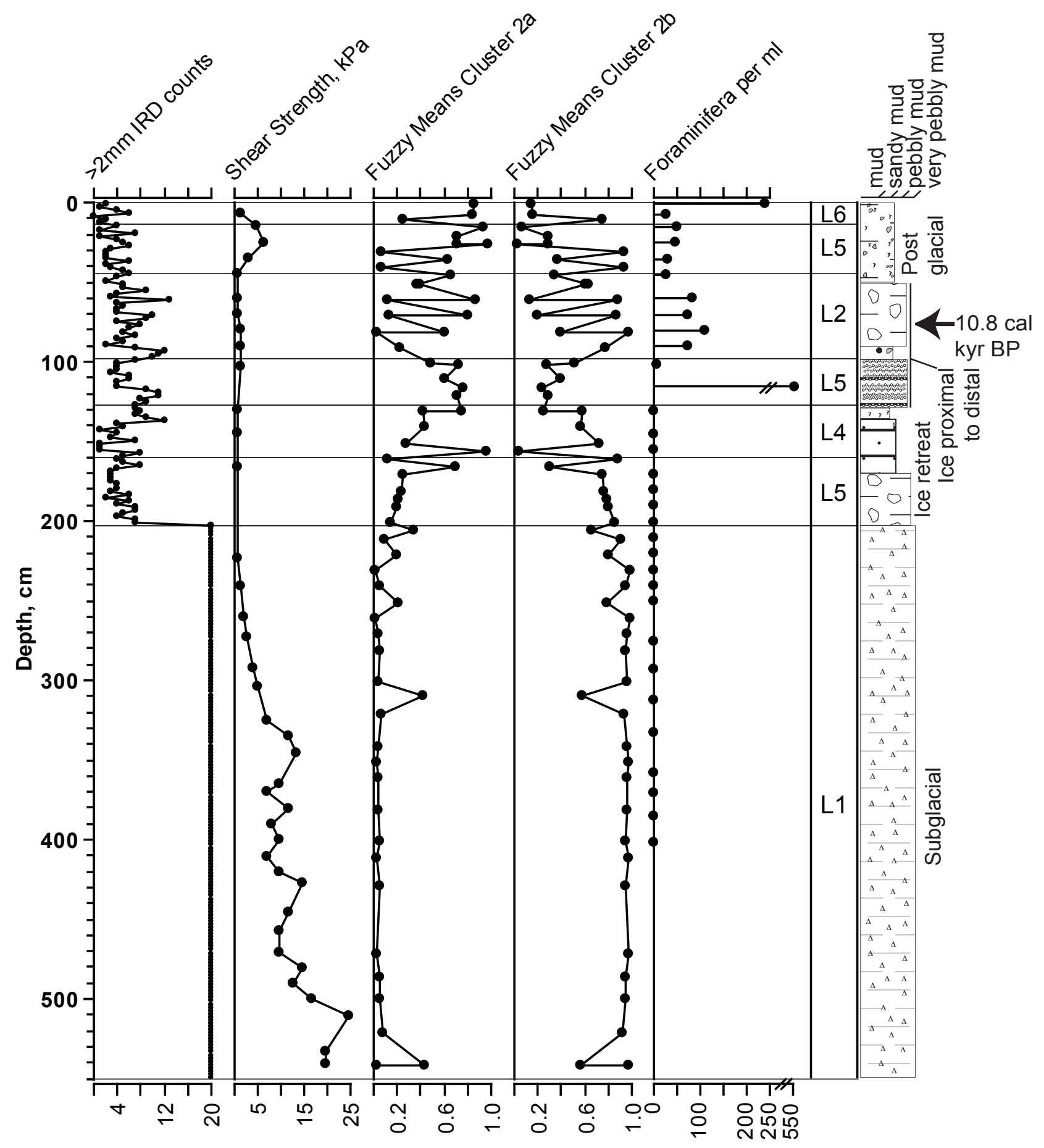




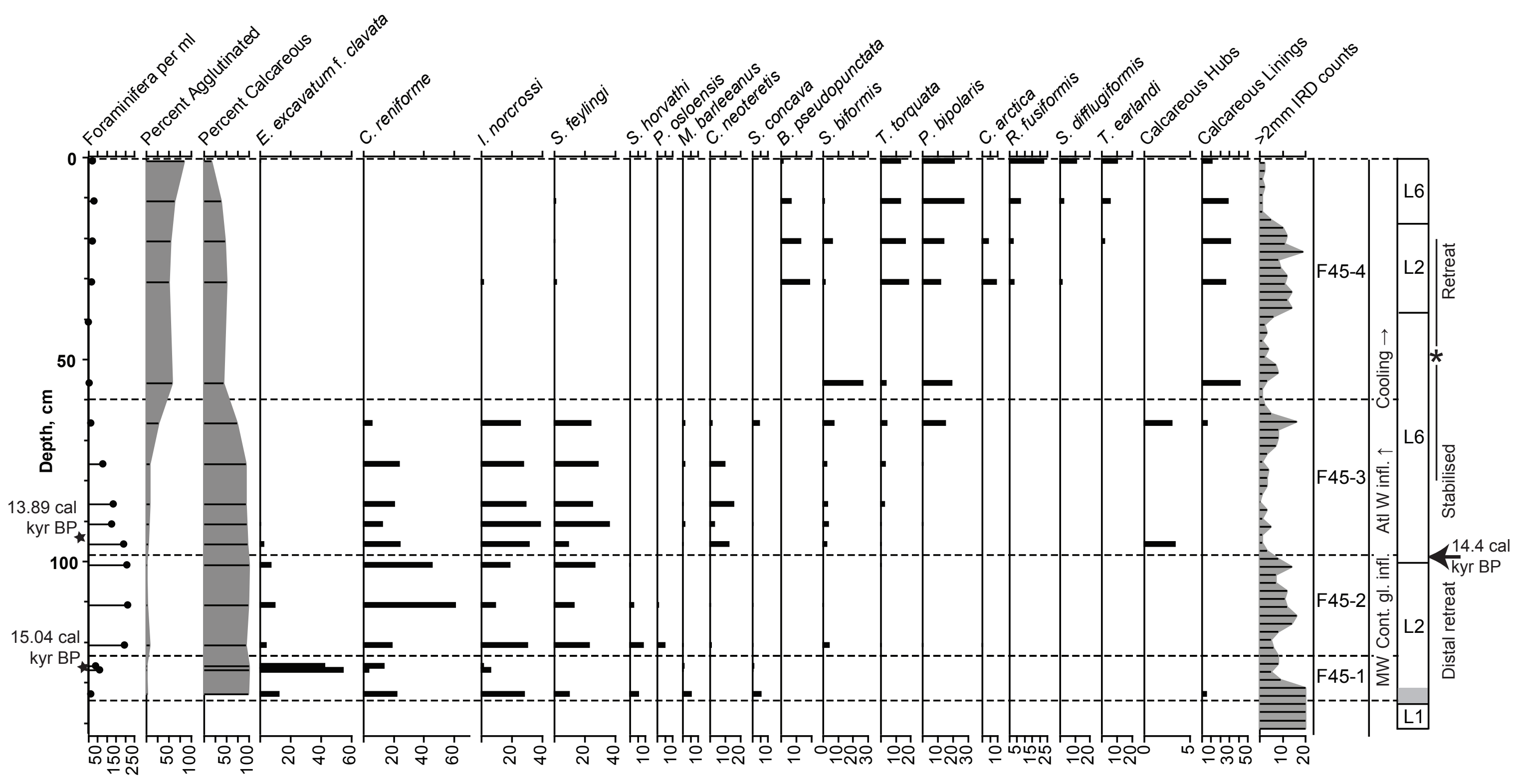




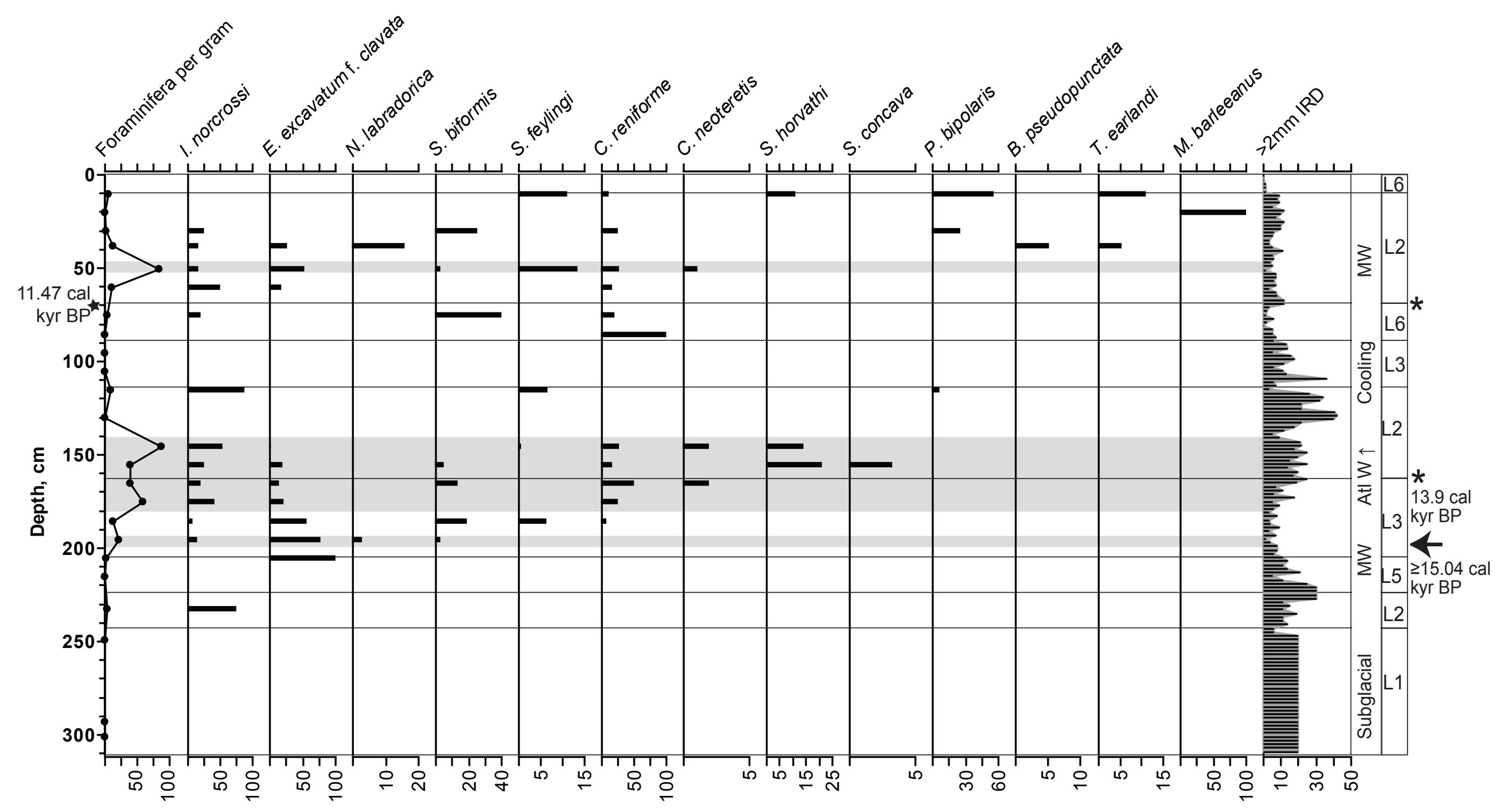




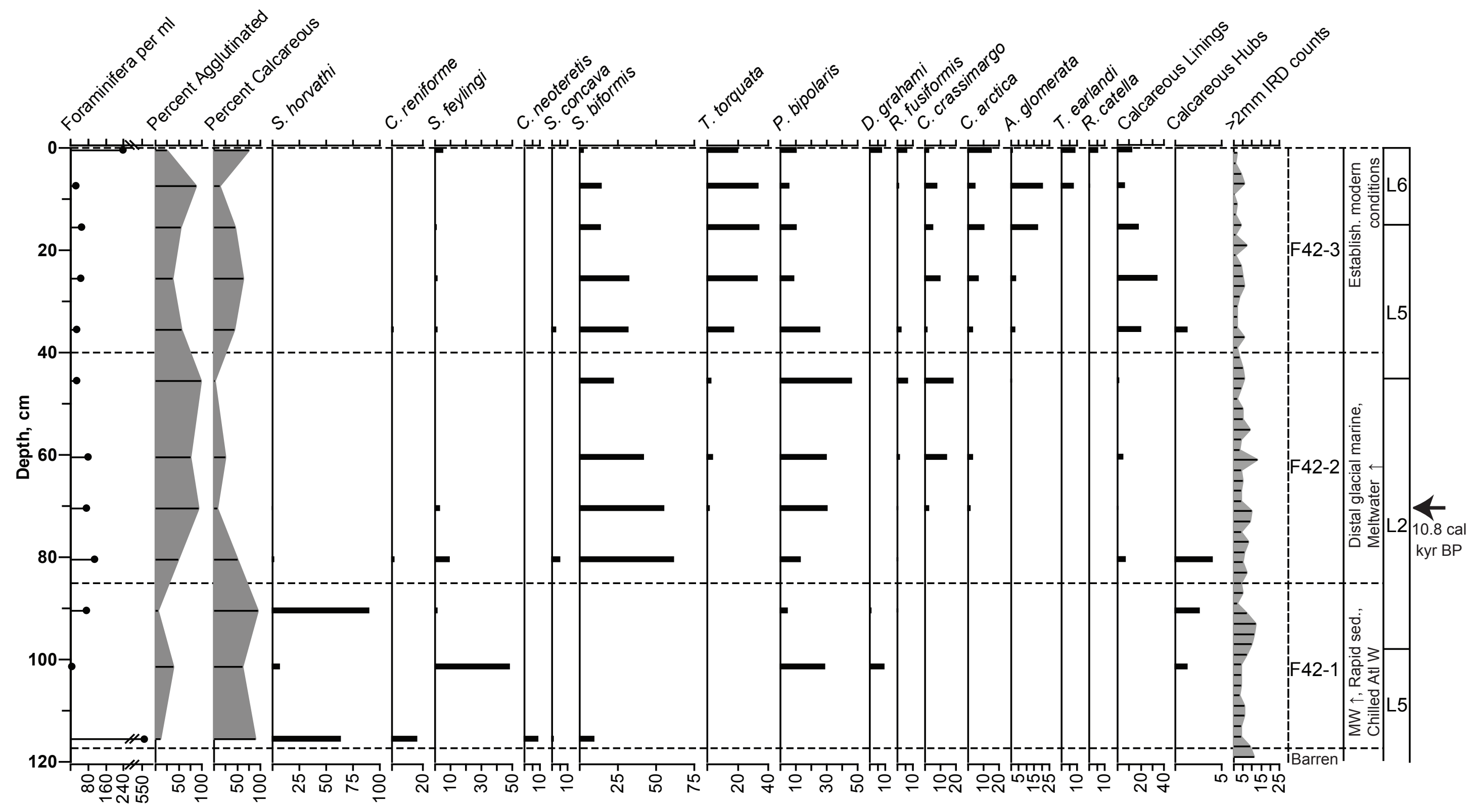




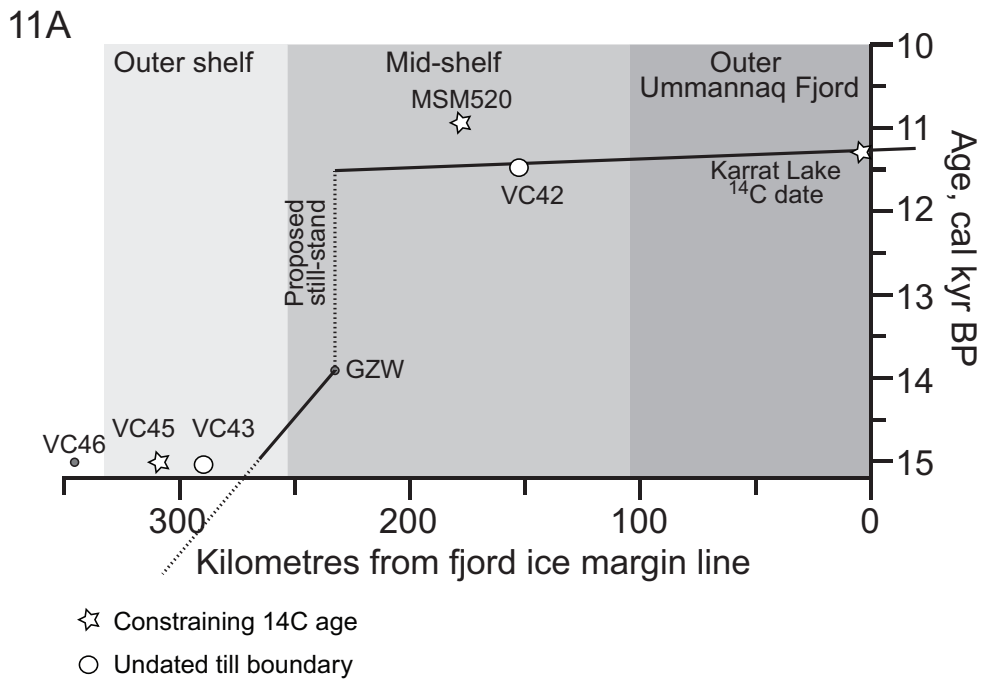

11B

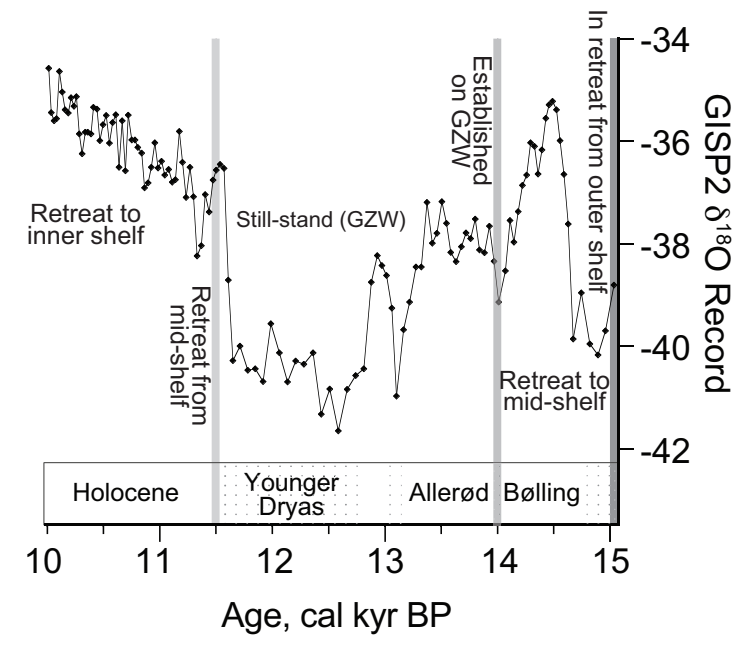

